\title{
CROPS AND SOILS RESEARCH PAPER The performance of the EU-Rotate_N model in predicting the growth and nitrogen uptake of rotations of field vegetable crops in a Mediterranean environment
}

\author{
C. NENDEL ${ }^{*}$, A. VENEZIA ${ }^{2}$, F. PIRO ${ }^{2}$, T. REN ${ }^{3}$, R. D. LILLYWHITE ${ }^{4}$ AND C. R. RAHN ${ }^{4}$ \\ ${ }^{1}$ Leibniz Centre for Agricultural Landscape Research, Institute of Landscape Systems Analysis, Eberswalder Straße 84, \\ 15374 Müncheberg, Germany \\ ${ }^{2}$ Centro di Ricerca per l'Orticoltura, Via dei Cavalleggeri 25, Casella Postale 48, 84098 Pontecagnano, Italy \\ ${ }^{3}$ College of Resources and Environmental Sciences, China Agricultural University, Beijing 100193, \\ People's Republic of China \\ ${ }^{4}$ School of Life Sciences, University of Warwick, Wellesbourne, Warwick CV35 9EF, UK
}

(Received 21 March 2011; revised 27 May 2012; accepted 24 July 2012)

\section{SUMMARY}

The EU-Rotate_N model was developed as a tool to estimate the growth and nitrogen $(\mathrm{N})$ uptake of vegetable crop rotations across a wide range of European climatic conditions and to assess the economic and environmental consequences of alternative management strategies. The model has been evaluated under field conditions in Germany and Norway and under greenhouse conditions in China. The present work evaluated the model using Italian data to evaluate its performance in a warm and dry environment. Data were collected from four 2-year field rotations, which included lettuce (Lactuca sativa L.), fennel (Foeniculum vulgare Mill.), spinach (Spinacia oleracea L.), broccoli (Brassica oleracea L. var. italica Plenck) and white cabbage (B. oleracea convar. capitata var. alba L.); each rotation used three different rates of $\mathrm{N}$ fertilizer (average recommended $\mathrm{N} 1$, assumed farmer's practice $\mathrm{N} 2=\mathrm{N} 1+0 \cdot 3 \times \mathrm{N} 1$ and a zero control $\mathrm{N} 0$ ). Although the model was not calibrated prior to running the simulations, results for above-ground dry matter biomass, crop residue biomass, crop $\mathrm{N}$ concentration and crop $\mathrm{N}$ uptake were promising. However, soil mineral $\mathrm{N}$ predictions to $0.6 \mathrm{~m}$ depth were poor. The main problem with the prediction of the test variables was the poor ability to capture $\mathrm{N}$ mineralization in some autumn periods and an inappropriate parameterization of fennel. In conclusion, the model performed well, giving results comparable with other bio-physical process simulation models, but for more complex crop rotations. The model has the potential for application in Mediterranean environments for field vegetable production.

\section{INTRODUCTION}

The fate of nitrogen $(\mathrm{N})$ in agricultural systems has been the subject of many investigations over the years, with its contribution to environmental pollution being of major concern (Sutton et al. 2011). The production of field vegetables can result in large $\mathrm{N}$ surpluses compared with other production systems, due to the greater supply of $\mathrm{N}$ to vegetable crops and the large amounts of $\mathrm{N}$-rich crop residues left after harvest (Agostini et al. 2010). Leaching is the major pathway for $\mathrm{N}$ loss and an important issue in countries where $\mathrm{N}$ input is still

* To whom all correspondence should be addressed. Email: nendel@zalf.de very high (Ramos et al. 2002; Cao et al. 2005). However, increasing concerns over the production of greenhouse gases and their effects on the climate has also focussed attention on gaseous $\mathrm{N}$ emissions, principally nitrous oxide (Mei et al. 2009). In commercial vegetable production, large amounts of $\mathrm{N}$ are unavoidably left in the soil after harvest, so research has focused on the improvement of $\mathrm{N}$ use efficiency (Zotarelli et al. 2009) and on the clarification of detailed $\mathrm{N}$ dynamics (Jackson 2000). Many strategies have been proposed to reduce $\mathrm{N}$ losses, including changes to cropping sequences (Dusenbury et al. 2008), more targeted application of fertilizer (Westerveld et al. 2006), precision irrigation 

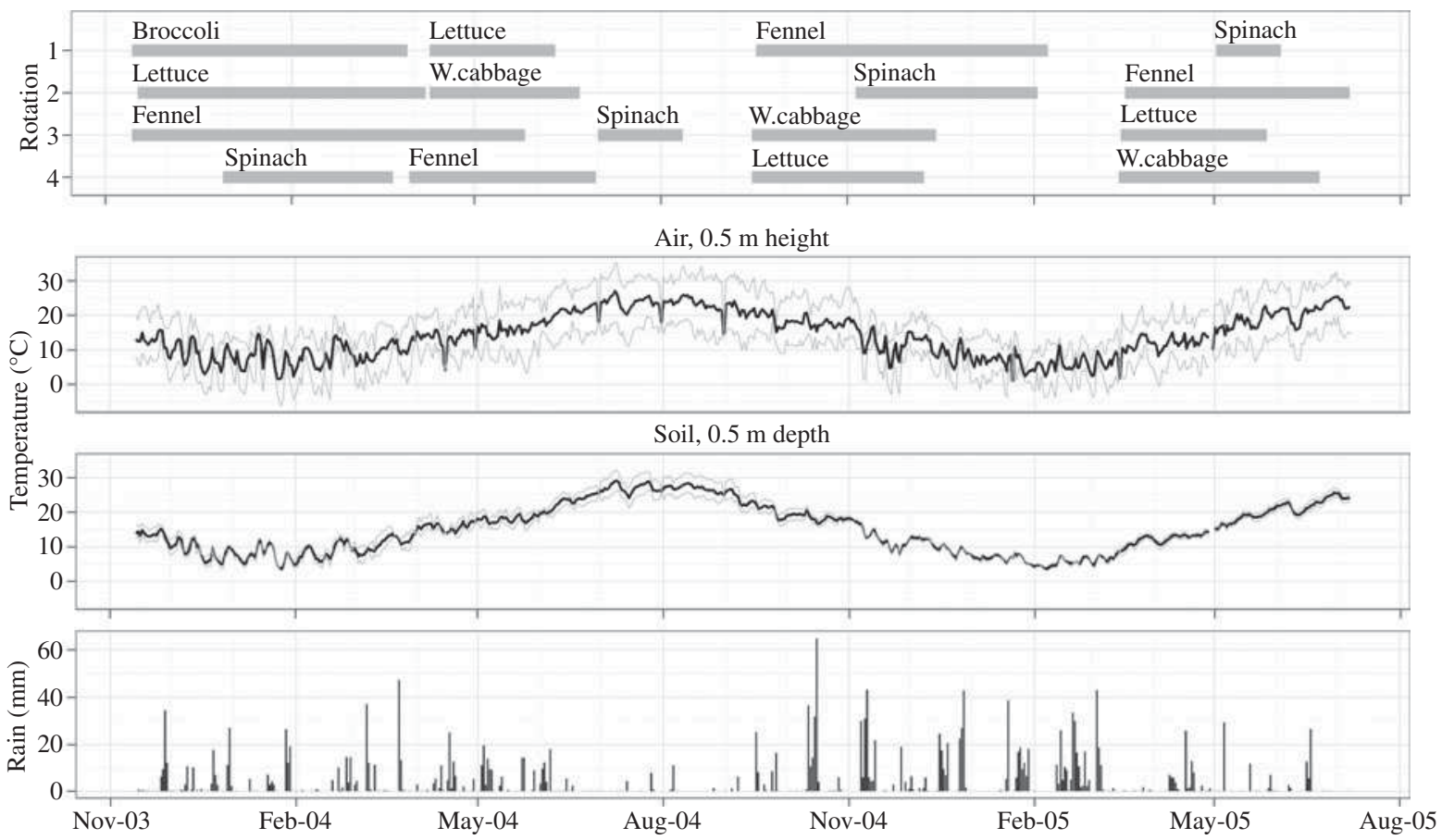

Fig. 1. Crop sequence and length in the four rotations, profiles of site air temperature at a height of $0.5 \mathrm{~m}$ and of soil temperature at a depth of $0 \cdot 1 \mathrm{~m}$ and the amount of precipitation during the period.

(Halvorson et al. 2008), fertigation (Gallardo et al. 2006), the use of organic N sources (Crews \& Peoples 2005) and different fertilizer types (Guertal 2009). Soilfertilizer-plant-water interactions are very complex (Wang et al. 2007); therefore, simulation models for agro-ecosystems were developed to further elucidate the fate of $\mathrm{N}$ in vegetable production and to compare different management strategies (Cavero et al. 1999).

Mediterranean countries share similar growing conditions for vegetable production and farmers' approaches to the use of fertilizer N. Consequently, resulting environmental problems are also comparable (Ramos et al. 2002). Modelling approaches have been applied to these vegetable production systems, i.e. in Italy (Lugato et al. 2007; Rinaldi et al. 2007), Spain (de Paz \& Ramos 2004), France (Lafolie et al. 1997; Leenhardt et al. 1998) and Turkey (Muhammetoglu \& Yardimci 2006). Unfortunately, all these approaches use simulation models which were not designed for the specific conditions and peculiarities of vegetable production.

The EU-Rotate_N simulation model (Rahn et al. 2010) was developed to predict $N$ dynamics for vegetable crops across Europe. However, to date this dynamic, process-based model has only been tested against a number of vegetable rotations in Germany and Norway (Rahn et al. 2010) and greenhouse crop rotations in China (Guo et al. 2010), but not in warm and dry field environments. To address this issue, the EU-Rotate_N model was used to estimate the growth and $\mathrm{N}$ uptake of crops using data taken from an experiment growing a range of field vegetables in rotation in Italy.

\section{MATERIALS AND METHODS}

Experimental crop rotations

Four 2-year crop rotations were grown at the CRA-ORT experimental station at Pontecagnano, Italy $\left(40^{\circ} 38^{\prime} \mathrm{N}\right.$, $\left.14^{\circ} 52^{\prime} \mathrm{E}\right)$. Each crop was supplied with three $\mathrm{N}$ levels and grown in two different seasons (spring-summer $v$. autumn-winter seasons) until completion of a four crop rotation. All rotations contained lettuce (Lactuca sativa L.), fennel (Foeniculum vulgare Mill.), spinach (Spinacia oleracea L.) and broccoli (Brassica oleracea L. var. italica Plenck) and were irrigated on demand. After the first season, white cabbage $(B$. oleracea convar. capitata var. alba L.) replaced broccoli due to its disappointing performance over winter (Fig. 1). Crops were chosen to investigate combinations of alternating rooting depths and different seasonal $\mathrm{N}$ requirements. Climate data used for modelling were recorded by a weather station on site. 
The first crops of rotations 1-3 (broccoli, fennel and lettuce) were transplanted in November 2003, after a crop of broad beans (Vicia faba L.) harvested in early summer; the land was left fallow between harvest and transplanting. White cabbage followed by sunflower (Helianthus annuus L.) had been grown the year before. The first crop of rotation 4 (spinach) was seeded at the end of the year. The second cycle started in April 2004 for lettuce, cabbage, fennel and a late spinach crop, which was delayed by the longer growing season of the preceding fennel crop and then failed partly due to a damaged sprinkler during a hot and windy period. The third cycle started in September 2004, following a 3-month summer fallow period for lettuce, fennel and white cabbage; spinach was sown in early October 2004. The fourth cycle started in March 2005 for cabbage, lettuce and fennel with spinach seeded at the beginning of April. The experiment ended in July 2005. This approach ensured that the same crops were observed twice in spring and twice in the autumnwinter season. Crop residue incorporation to a tillage depth of $0 \cdot 2 \mathrm{~m}$ occurred within 1 week of harvesting.

Three $\mathrm{N}$ treatments were used: the average of official national and regional recommendations for the crop (N1), an assumed farmer's common practice rate, i.e. $\mathrm{N} 1+0 \cdot 3 \times \mathrm{N} 1(\mathrm{~N} 2)$ and a zero rate for the control (N0). The farmer's rate for each vegetable species was defined by gathering information from agricultural magazines and agricultural consultants operating in the CRA-ORT area. A split-plot field layout was used, with rotation as the main plot and $\mathrm{N}$ rate in subplots of $75 \mathrm{~m}^{2}(5 \times 15 \mathrm{~m})$; each treatment was replicated twice with each replicate in a separate block. The $\mathrm{N}$ rate for each crop was fixed and applied irrespective of the preceding crop sequence. Ammonium sulphate was used for the base $\mathrm{N}$ dressing and ammonium nitrate for top dressing (Table 1).

The site was located in the coastal plain south of Salerno, a major vegetable growing area; the soil was a deep and well-drained loam with mass fractions of 0.43 sand, 0.18 clay and 0.39 silt, $0.035 \mathrm{~kg}$ organic matter/kg soil and a $C: N$ ratio of 10 . A former citrus orchard, the site had been intensively amended with sunflower stalk mulch before being turned into permanent grassland for 2 years. After being converted into a vegetable field, broad beans were the principal crop grown on it in vegetable rotations. Irrigation was applied with a low-pressure sprinkler system.

Above-ground biomass and its $\mathrm{N}$ content were determined by sampling three to seven times for dry matter and two to five times for crop $\mathrm{N}$ during the
Table 1. Nitrogen fertilizer application rates for the different fertilizing strategies NO (control), N1 (recommended rate) and N2 (farmer's practice $\mathrm{N} 1+30 \%)$

\begin{tabular}{|c|c|c|c|c|}
\hline \multirow[b]{2}{*}{ Crop } & \multicolumn{3}{|c|}{$\mathrm{N}$ rates $(\mathrm{kg} \mathrm{N} / \mathrm{ha})$} & \multirow[b]{2}{*}{ Application timing } \\
\hline & No & N1 & $\mathrm{N} 2$ & \\
\hline $\begin{array}{l}\text { Broccoli/ } \\
\text { cabbage }\end{array}$ & 0 & 250 & 325 & $\begin{array}{l}0.33 \text { at transplanting, } \\
30 \text { and } 60 \text { days later }\end{array}$ \\
\hline Fennel & 0 & 200 & 260 & $\begin{array}{l}0 \cdot 33 \text { at transplanting, } \\
30 \text { and } 60 \text { days later }\end{array}$ \\
\hline Spinach & 0 & 150 & 195 & $\begin{array}{l}0.50 \text { at transplanting } \\
\text { and } 30 \text { days later }\end{array}$ \\
\hline Lettuce & 0 & 160 & 208 & $\begin{array}{l}0.50 \text { at transplanting } \\
\text { and } 30 \text { days later }\end{array}$ \\
\hline
\end{tabular}

growing season with the final sample taken at harvest. A sample consisted of a number of plants varying by species and growth stage. The numbers of plants taken at harvest and transplanting stages were: 5 and 20 plants, respectively, for broccoli; 5 and 30, respectively, for cabbage; 10 and 40 for lettuce and 20 and 100 for spinach. Dry matter was determined by oven drying and subsequent weighing. Above-ground dry matter $\mathrm{N}$ concentration was determined using the Kjeldahl method for total $\mathrm{N}$ and ionic chromatography on aqueous extracts for nitrate N (ICS 1500, Dionex, Sunnyvale, CA, USA). Nitrogen uptake was calculated from dry matter and $\mathrm{N}$ concentration. Soil mineral $\mathrm{N}$ was determined twice on soil samples taken at two depths $(0-0.3$ and $0 \cdot 3-0 \cdot 6 \mathrm{~m})$. The first sample was taken at planting before the application of $\mathrm{N}$ and the second after harvest. Samples were immediately frozen at $-30{ }^{\circ} \mathrm{C}$ for storage until analysis. Soil mineral $\mathrm{N}$ was extracted using sodium carbonate $(1.8 \mathrm{mmol} / \mathrm{l})$ and bicarbonate $(1.7 \mathrm{mmo} / \mathrm{l})$ for nitrate and metansulphonic acid (20 mmol/l) for ammonium and analysed in solution using an ICS1500 ionic exchange chromatographer (Dionex, USA), with AS4A-SC and CS-12A columns, respectively.

\section{The EU-Rotate_N simulation model}

The dynamic, process-based simulation model EU-Rotate_N was developed as a tool to optimize $\mathrm{N}$ use in horticultural crop rotations across Europe (Rahn et al. 2010). In part, it was based on the single season N_ABLE model (Greenwood et al. 1996). EU-Rotate_N simulates crop-soil interactions in vegetable crop rotations, mainly on a process basis using daily time steps. Nitrogen movement in soil is driven by water 
balance and transport. Water movement in soil follows a capacity approach, for which the water content at saturation, field capacity and wilting point define the hydraulic soil properties. Crop evapotranspiration is calculated using Penman-Monteith algorithms (Allen et al. 1998) and crop-specific correction factors ( $K_{\mathrm{c}}$ values). In simulations, water stress reduces plant growth linearly with decreasing available soil moisture, as soon as it falls below a user-defined critical deficit. If the simulated average soil moisture in the rooting zone is below the permanent wilting point, crop growth ceases.

Crop growth follows a target yield approach, for which a maximum achievable yield needs to be provided on the basis of the user's experience. This approach is considered the most feasible, considering the vast range of different crop types and morphologies among field vegetables and the resulting difficulties in applying generic photosynthesis-driven algorithms. Marketable parts of the crops and, correspondingly, the amount of residues to remain in the field are calculated using a population approach for row crops providing a single product per plant and a regression approach for others (Nendel et al. 2009). The population approach uses crop-specific dry matter concentrations and a distribution coefficient for individual weights to calculate a fresh weight distribution of the plant population. For user-defined upper and lower boundaries of marketable produce the fresh marketable yield is calculated. Individual plants producing marketable parts outside the boundary conditions (i.e. at insufficient water or $\mathrm{N}$ supply or inappropriate planting space) are treated as crop residues, assuming that they would be graded out and left in or brought back to the field immediately. This approach reflects the water and $\mathrm{N}$ availability to individual plants at varying planting spaces. For non-row crops an empirical transfer function was used to calculate fresh marketable yield for different $\mathrm{N}$ supply levels (Nendel et al. 2009).

Crop residues were assigned a dynamic $\mathrm{C}: \mathrm{N}$ ratio, which reflects the $\mathrm{N}$ supply of the crop during the growth period. Default $\mathrm{C}: \mathrm{N}$ ratios and partitioning coefficients for crop residues were derived from stepwise chemical digestion experiments (Jensen et al. 2005).

Organic matter turnover, including $\mathrm{N}$ mineralization, denitrification and $\mathrm{CO}_{2}$ release were based on algorithms from the DAISY model (Hansen et al. 1991). The pool concept includes two pools each for fresh added organic matter, microbial biomass and soil organic matter, representing a fraction of organic matter with slow and one with rapid turnover rates. The pools are carbon (C) pools, from which $\mathrm{N}$ is released or immobilized during turnover processes according to increasing or decreasing $C: N$ ratios during mass transfer between pools of fixed $\mathrm{C}: \mathrm{N}$ ratios. The turnover rates are taken from DAISY standards.

Root growth is calculated by a thermal time approach and distributed spatially in a 2D soil cell grid (Pedersen et al. 2010), allowing for the simulation of spacing effects in row crops (Nendel et al. 2009). Crop and soil-specific rooting depth enables deep and shallow rooted crops, and their characteristic $\mathrm{N}$ exploitation from the soil, to be simulated. Nitrogen uptake is calculated as a function of crop $\mathrm{N}$ demand and the potential root $\mathrm{N}$ uptake. Crop critical $\mathrm{N}$ content is calculated according to Greenwood (2001), allowing for luxury $\mathrm{N}$ consumption in typical vegetables using a crop-specific surplus factor. The critical $\mathrm{N}$ curve (or luxury $\mathrm{N}$ curve, respectively) determines the $\mathrm{N}$ demand of the crop. If the $\mathrm{N}$ demand cannot be met due to insufficient $\mathrm{N}$ available in the rooted soil or due to low soil water contents that limit $\mathrm{N}$ transport towards the root, a reduction factor proportional to the $\mathrm{N}$ deficit reduces daily growth. Once growth is reduced by $\mathrm{N}$ or water shortage, the specified target yield at harvest can no longer be met.

Nitrogen fertilizer applications can be input directly, specifying date, amount and fertilizer type. Different $N$ fertilizers are provided in a database, distinguished by percentages of ammonia, nitrate and carbamide content. In addition, a triggered fertilizer strategy is provided by the model (Nendel 2009). A database containing European standard prices for marketable crops and standard figures for gross margin calculation supports the economic output of the model, enabling the simultaneous evaluation of management effects on both the environment and economic returns (Nendel 2009).

Model settings and input variables

Simulations were performed for the treatments (crop rotations by $\mathrm{N}$ input levels) with version 1.5 of the EU-Rotate_N model (Rahn et al. 2010). These followed the observed time schedules for each rotation, and the results were compared with the observations (average of replicates). The optional surface run-off calculation was turned off. Soil water content at saturation was calculated from soil texture according to Saxton et al. (1986), with a ceiling at 1-(bulk density)/2·65. Initial 
Table 2. Soil information input into the EU-Rotate_N model

\begin{tabular}{|c|c|c|c|c|}
\hline Soil variable & Unit & $0-0 \cdot 3 \mathrm{~m}$ & $0.3-0.6 \mathrm{~m}$ & $0.6-0.9 \mathrm{~m}^{*}$ \\
\hline Clay content & $\mathrm{kg} / \mathrm{kg}$ & $0 \cdot 169$ & $0 \cdot 181$ & $0 \cdot 156$ \\
\hline Sand content & $\mathrm{kg} / \mathrm{kg}$ & $0 \cdot 431$ & $0 \cdot 416$ & $0 \cdot 442$ \\
\hline Bulk density & $\mathrm{kg} / \mathrm{m}^{3}$ & 1115 & 1090 & 1090 \\
\hline Soil pH value & & $7 \cdot 95$ & $8 \cdot 05$ & $8 \cdot 15$ \\
\hline OM content & kg/kg & $0 \cdot 0371$ & 0.0358 & $0 \cdot 0245$ \\
\hline Field capacity & $\mathrm{m}^{3} / \mathrm{m}^{3}$ & $0 \cdot 226$ & $0 \cdot 223$ & $0 \cdot 216$ \\
\hline $\begin{array}{l}\text { Permanent } \\
\text { wilting point }\end{array}$ & $\mathrm{m}^{3} / \mathrm{m}^{3}$ & $0 \cdot 127$ & $0 \cdot 126$ & $0 \cdot 12$ \\
\hline Saturation & $\mathrm{m}^{3} / \mathrm{m}^{3}$ & $0 \cdot 457$ & $0 \cdot 462$ & $0 \cdot 452$ \\
\hline $\begin{array}{l}\text { Drainage } \\
\text { coefficient }\end{array}$ & & $0 \cdot 2$ & $0 \cdot 2$ & $0 \cdot 2$ \\
\hline
\end{tabular}

* The model assumes input variables from the lowest defined soil horizon valid for the soil profile below down to $2 \mathrm{~m}$ depth.

conditions for soil moisture and mineral $\mathrm{N}$ content (as $\mathrm{NO}_{3}-\mathrm{N}$ ) were set as observed in two soil layers down to $0.6 \mathrm{~m}$ depth at the start of the experiment, with no further update for soil mineral N. Soil information used as input for the model is summarized in Table 2. The ratio between soil moisture deficit and the corresponding dry matter weight reduction due to water stress was set to $0 \cdot 1$, while defaults ( 0 ) have been used for minimum and maximum fresh weight per marketable part of the crop and variability coefficient of marketable yield. The target yields for each season were set from the maximum dry matter yields achieved in the experiments for each crop-season combination (Table 3).

\section{Model performance evaluation}

Model performance was evaluated by comparisons between observations and model predictions for aboveground dry biomass, amount of crop residue biomass, above-ground biomass $\mathrm{N}$ concentration, crop $\mathrm{N}$ uptake and soil mineral $\mathrm{N}$ content. Overall evaluation by crop was based on the following summary statistics for forecast verification (Stanski et al. 1989), which were calculated on paired predictions and means of replicate observations. The percent bias of prediction (PBIAS) was calculated as:

PBIAS $=100 \times \frac{\sum_{i=1}^{n}\left(P_{i}-O_{i}\right)}{\sum_{i=1}^{n} O_{i}}$

where $n$ is the size of the sample, $P$ is the predicted value and $O$ the observed value. This is the average difference between predicted and observed as percentage of observed mean (range $=0:+\infty$ ), used to assess prediction bias in relation to the average magnitude of the observed. The mean absolute prediction error (MAE, Shaeffer 1980) was calculated as:

$\mathrm{MAE}=\sum_{i=1}^{n} \frac{\left|P_{i}-O_{i}\right|}{n}$

It is the average of absolute differences between predicted and observed (range $=0:+\infty$ ), employed to calculate the average magnitude of prediction errors, irrespective of their direction. Willmott's index of agreement ( $d$, Willmott \& Wicks 1980) was calculated as:

$d=1-\frac{\sum_{i=1}^{n}\left(P_{i}-O_{i}\right)^{2}}{\sum_{i=1}^{n}\left(\left|P_{i}-\bar{O}\right|+\left|O_{i}-\bar{O}\right|\right)^{2}}$

where $\bar{O}$ is the mean of the observed values. This is a standardized measure of the degree of model prediction error and proportionality between predictions and observations with a range $0: 1 \quad(1=$ perfect agreement; $0=$ no agreement at all). It is more consistent than the linear correlation coefficient, but sensitive to extreme values, due to the squared differences. Finally, the Nash-Sutcliffe efficiency index (EF, Nash \& Sutcliffe 1970) was calculated as:

$\mathrm{EF}=1-\frac{\sum_{i=1}^{n}\left(P_{i}-O_{i}\right)^{2}}{\sum_{i=1}^{n}\left(O_{i}-\bar{O}\right)^{2}}$

This is a normalized measure of the relative magnitude of the data variance (information) compared with the residual variance (noise), with the range $-\infty$ to 1 $(1=$ perfect fit; $0=$ predictions are as accurate as the mean of the observed data; $-\infty<0=$ predictions worse than the mean of observed).

Model performance in relation to the experimental factors was further assessed with an analysis of variance (ANOVA) by crop species of the difference between the unique model predictions and the replicated observations for the combinations of rotation $\times \mathrm{N}$ treatment $\times$ crop stage, according to the split-plot design of the field layout, with crop stages within $\mathrm{N}$ treatments within rotation within blocks, summarized as:

$$
\begin{aligned}
y_{i j k l}= & m+\text { block }_{i}+\text { rotation }_{i j}+\mathrm{N} \text { treatment }_{i j k} \\
& + \text { crop stage }_{i j k l}
\end{aligned}
$$

where $i=1: 2, j=1: 4, k=1: 3$ and $I=1: n$, with $n$ varying by crop and response variable. Crop stage is not relevant for crop residues. The boundary given by 
Table 3. Management data for the crops in the four rotations, including sowing/transplanting dates, total amount of irrigation and number of irrigation events, target yield, $N$ concentration in transplant, dry weight of transplant, row width and plant spacing, as used as input information for the EU-Rotate_N model

\begin{tabular}{|c|c|c|c|c|c|c|c|c|c|c|}
\hline $\begin{array}{l}\text { Rotation } \\
\text { and crop }\end{array}$ & $\begin{array}{l}\text { Sowing/Transplant } \\
\text { date }\end{array}$ & Harvest date & $\begin{array}{l}\text { Irrigation } \\
\text { amount mm }\end{array}$ & $\begin{array}{l}\text { No. irrigation } \\
\text { events }\end{array}$ & $\begin{array}{l}\text { Dry matter } \\
\text { target } \\
\text { yield t/ha }\end{array}$ & $\begin{array}{l}\text { Sown/ } \\
\text { Transplanted }\end{array}$ & $\begin{array}{l}\mathrm{N} \text { in } \\
\text { transplants } \\
\mathrm{g} / 100 \mathrm{~g}\end{array}$ & $\begin{array}{l}\text { Dry weight at } \\
\text { transplanting } \\
\mathrm{kg} / \mathrm{ha}\end{array}$ & $\begin{array}{l}\text { Row } \\
\text { width m }\end{array}$ & Spacing $\mathrm{m}$ \\
\hline \multicolumn{11}{|l|}{ Rotation 1} \\
\hline Broccoli & 14 November 2003 & 29 March 2004 & $18 \cdot 0$ & 1 & $3 \cdot 9$ & Transplanted & $4 \cdot 1$ & $50 \cdot 0$ & $0 \cdot 60$ & $0 \cdot 40$ \\
\hline Lettuce & 09 April 2004 & 9 June 2004 & $34 \cdot 7$ & 5 & $1 \cdot 9$ & Transplanted & $2 \cdot 3$ & $17 \cdot 0$ & $0 \cdot 30$ & $0 \cdot 40$ \\
\hline Fennel & 17 September 04 & 8 February 2005 & $70 \cdot 6$ & 8 & $5 \cdot 0$ & Transplanted & $2 \cdot 1$ & $7 \cdot 0$ & $0 \cdot 60$ & $0 \cdot 20$ \\
\hline Spinach & 08 April 2005 & 1 June 2005 & $57 \cdot 0$ & & $3 \cdot 5$ & Sown & - & - & $0 \cdot 30$ & $0 \cdot 05$ \\
\hline \multicolumn{11}{|l|}{ Rotation 2} \\
\hline Lettuce & 17 November 2003 & 5 April 2004 & $18 \cdot 0$ & 1 & $2 \cdot 0$ & Transplanted & $5 \cdot 4$ & $4 \cdot 0$ & $0 \cdot 30$ & $0 \cdot 40$ \\
\hline Cabbage & 09 April 2004 & 23 June 2004 & $15 \cdot 6$ & 3 & $9 \cdot 5$ & Transplanted & $1 \cdot 7$ & $50 \cdot 0$ & $0 \cdot 60$ & $0 \cdot 40$ \\
\hline Spinach & 04 October 2004 & 2 February 2005 & $105 \cdot 1$ & 12 & $2 \cdot 0$ & Sown & - & - & $0 \cdot 30$ & $0 \cdot 05$ \\
\hline Fennel & 17 March 2005 & 05 July 2005 & $129 \cdot 2$ & 15 & $7 \cdot 8$ & Transplanted & $1 \cdot 4$ & $8 \cdot 0$ & $0 \cdot 60$ & $0 \cdot 20$ \\
\hline Rotation 3 & & & & & & Transplanted & & & & \\
\hline Fennel & 14 November 2003 & 24 May 2004 & $22 \cdot 1$ & 2 & $8 \cdot 9$ & Transplanted & $2 \cdot 1$ & $8 \cdot 7$ & $0 \cdot 60$ & $0 \cdot 20$ \\
\hline Spinach & 01 July 2004 & 11 August 2004 & $204 \cdot 6$ & 24 & $2 \cdot 8$ & Sown & - & - & $0 \cdot 30$ & $0 \cdot 05$ \\
\hline Cabbage & 15 September 2004 & 14 December 2004 & $40 \cdot 6$ & 6 & $4 \cdot 9$ & Transplanted & 1.9 & $19 \cdot 9$ & $0 \cdot 60$ & $0 \cdot 40$ \\
\hline Lettuce & 16 March 2005 & 26 May 2005 & $57 \cdot 1$ & 9 & $3 \cdot 3$ & Transplanted & $1 \cdot 0$ & $8 \cdot 7$ & $0 \cdot 30$ & $0 \cdot 40$ \\
\hline \multicolumn{11}{|l|}{ Rotation 4} \\
\hline Spinach & 18 November 2003 & 24 March 2004 & $4 \cdot 5$ & 1 & $2 \cdot 0$ & Sown & - & - & $0 \cdot 30$ & $0 \cdot 05$ \\
\hline Fennel & 31 March 2004 & 5 July 2004 & $36 \cdot 8$ & 7 & $5 \cdot 9$ & Transplanted & $2 \cdot 2$ & $10 \cdot 0$ & $0 \cdot 60$ & $0 \cdot 20$ \\
\hline Lettuce & 15 September 2004 & 6 December 2004 & $68 \cdot 5$ & 7 & $2 \cdot 0$ & Transplanted & $1 \cdot 7$ & $13 \cdot 0$ & $0 \cdot 30$ & $0 \cdot 40$ \\
\hline Cabbage & 15/ March 2005 & 21 June 2005 & $135 \cdot 8$ & 16 & $9 \cdot 6$ & Transplanted & $2 \cdot 0$ & $50 \cdot 0$ & $0 \cdot 60$ & $0 \cdot 40$ \\
\hline
\end{tabular}


the $95 \%$ confidence interval of the difference relative to zero was considered for assessing model adequacy at each experimental condition, with intervals including zero, showing a prediction error not larger than the experimental error of the mean estimates. The ANOVA also allows an assessment of the respective impact of the experimental factors on the adequacy of predictions. Data analyses were performed with the $R$ software environment ( $R$ Development Core Team 2011), using functions of the contributed packages hydroGOF (Zambrano-Bigiarini 2010) for computing the summary statistics and ggplot2 (Wickham 2009) for graphical displays.

\section{RESULTS}

\section{Above-ground biomass}

Dry matter yield varied by crop species between averages of $1.6 \mathrm{t} / \mathrm{ha}$ for spinach and $6.4 \mathrm{t} / \mathrm{ha}$ for white cabbage and was considerably higher for springsummer crops, $4 \cdot 1$ t/ha on average $v .3 \cdot 2$ t/ha for autumn-winter crops, with seasonal differences for crops of the same species largest for cabbage (Table 4). Dry matter generally increased for most crops, as expected, with $\mathrm{N}$ treatments $\mathrm{N} 1$ and $\mathrm{N} 2$ compared with $\mathrm{N} 0$, with little or no increase between $\mathrm{N} 1$ and $\mathrm{N} 2$, given the relatively minor difference between the respective input levels (Table 4 ). White cabbage in the first rotation, fennel in the fourth and lettuce in the first and fourth showed little benefit from $\mathrm{N}$ input, but only the autumn-winter fennel in the first rotation and the spring-summer spinach in the third did not show a positive response to $\mathrm{N}$ input, because of partial failure. The average increase across rotation of above-ground dry matter for the higher $\mathrm{N}$ input was $32 \%$ for lettuce, $28 \%$ for fennel, $22 \%$ for spinach and $78 \%$ for white cabbage, while a $130 \%$ increase was observed for the single crop of broccoli. The average increase by rotation across crops was $40 \%$ for the cold season (autumn-winter) and $51 \%$ for the warm season (spring-summer).

In terms of the summary measures, model predictions of biomass growth and yield were better for white cabbage, lettuce and broccoli, with little overall bias $(\mathrm{MAE}=0 \cdot 15-0 \cdot 34 \mathrm{t} / \mathrm{ha})$ and high correlation indices $(d=0.97-0.99 ; \mathrm{EF}=0 \cdot 88-0.96)$ (Table 5). Predictions of fennel dry matter were only slightly less accurate, while those for spinach were positively biased.

The prediction bias for the dry matter yield of broccoli is within the confidence band at the initial stages for all $\mathrm{N}$ treatments and at the final stage for $\mathrm{N} 1$ and $N 2$, because of the large coefficient of variation for this crop, yet an intermediate stage for $\mathrm{N} 1$ and $\mathrm{N} 2$ and the final stage for NO are over-predicted (Fig. 2). The ANOVA for white cabbage gives an assessment of the goodness of fit that is rather less optimistic than the summary statistics, due to the relatively low coefficient of variation compared with the other crop species, showing substantial under-prediction for $\mathrm{NO}$ in the advanced crop stages in rotations 1 and 2 and for N1 and $\mathrm{N} 2$ in the pre-final stages in rotation 3. Predictions for fennel dry matter show a similar pattern in the first three rotations, with some intermediate or late stages biased upward for N1 and N2 and downward for N0; for the last crop fewer points were observed and the model under-predicts $\mathrm{N} 0$ more than $\mathrm{N} 1$ and $\mathrm{N} 2$. Lettuce dry matter is predicted fairly well for $\mathrm{N} 1$ and $\mathrm{N} 2$ in all rotations and for $\mathrm{N} 0$ in the first two rotations; only the later stages of $\mathrm{N} 0$ are under-predicted in rotations 3 and 4 . Predictions of spinach dry matter are good for the autumn-winter crops (rotations 2 and 4), but tend to diverge with crop stage for the springsummer crops, to upward bias for $\mathrm{N} 1$ and $\mathrm{N} 2$ and downward bias for NO.

\section{Crop residues}

Crop residues were higher for broccoli and fennel, both in absolute terms and relative to above-ground biomass (70 and 50\%, respectively) and lower for spinach and lettuce (30 and $20 \%$, respectively), high in absolute and low in relative terms $(20 \%)$ for cabbage and tended to increase with increasing $N$ input (Table 4). Average increase by crop species ranged from $24 \%$ for fennel to $116 \%$ for broccoli, but some crops of each species apart from broccoli showed little increase (cabbage in rotation 3, lettuce in rotation 1 and fennel in rotations 1 and 4) or decrease (lettuce in rotation 4 and spinach in rotation 3). Averaged by rotation and season across crops, residues increased with the higher $\mathrm{N}$ input (N2) by $42 \%$ for both autumnwinter and spring-summer crops.

Summary statistics show better prediction of fennel and broccoli residues, with slight negative bias for the first and positive bias for the second (Table 5). The correlation indices for cabbage, lettuce and spinach, particularly the EF coefficient, point to a poor overall fit, though the average bias is large and positive, only for cabbage.

The error of prediction varies with the $N$ treatment more for the fennel crops, where it tends to shift from 
Table 4. Means of observed $(O)$ and model-predicted minus observed $(P-O)$ values for above-ground and crop residue biomass for five crops at three $N$ input treatments ( $N$, none; $N 1$, recommended rate and $N 2$, farmer's practice rate) in four rotations

\begin{tabular}{|c|c|c|c|c|c|c|c|c|c|c|c|c|c|c|}
\hline \multirow{3}{*}{$\begin{array}{l}\text { Rotation, season } \\
\text { and crop }\end{array}$} & \multicolumn{7}{|c|}{ Above-ground dry matter (t/ha) } & \multicolumn{7}{|c|}{ Residue dry matter (t/ha) } \\
\hline & \multicolumn{2}{|c|}{ No } & \multicolumn{2}{|c|}{ N1 } & \multicolumn{2}{|c|}{$\mathrm{N} 2$} & \multirow[b]{2}{*}{ S.E.D. } & \multicolumn{2}{|c|}{ No } & \multicolumn{2}{|c|}{ N1 } & \multicolumn{2}{|c|}{$\mathrm{N} 2$} & \multirow[b]{2}{*}{ S.E.D. } \\
\hline & $\mathrm{O}$ & $\mathrm{P}-\mathrm{O}$ & $\mathrm{O}$ & $\mathrm{P}-\mathrm{O}$ & $\mathrm{O}$ & $\mathrm{P}-\mathrm{O}$ & & $\mathrm{O}$ & $\mathrm{P}-\mathrm{O}$ & $\mathrm{O}$ & $\mathrm{P}-\mathrm{O}$ & $\mathrm{O}$ & $\mathrm{P}-\mathrm{O}$ & \\
\hline \multicolumn{15}{|l|}{ Broccoli } \\
\hline 1-AW & $1 \cdot 6$ & $1 \cdot 0$ & $3 \cdot 6$ & $0 \cdot 0$ & $3 \cdot 8$ & $-0 \cdot 1$ & $0 \cdot 24$ & $1 \cdot 15$ & $0 \cdot 8$ & $2 \cdot 4$ & $0 \cdot 3$ & $2 \cdot 5$ & $0 \cdot 4$ & $0 \cdot 19$ \\
\hline \multicolumn{15}{|l|}{ White cabbage } \\
\hline 2-SS & $4 \cdot 4$ & $-1 \cdot 7$ & $8 \cdot 9$ & $-0 \cdot 3$ & $9 \cdot 1$ & $-0 \cdot 2$ & & $0 \cdot 8$ & $-0 \cdot 1$ & $1 \cdot 5$ & $0 \cdot 7$ & $1 \cdot 7$ & $0 \cdot 5$ & \\
\hline 3-AW & $4 \cdot 4$ & $-1 \cdot 6$ & $4 \cdot 4$ & $0 \cdot 1$ & $4 \cdot 7$ & $0 \cdot 0$ & & $0 \cdot 8$ & $0 \cdot 0$ & $0 \cdot 8$ & $0 \cdot 3$ & $0 \cdot 8$ & $0 \cdot 4$ & \\
\hline 4-SS & $3 \cdot 8$ & 0.7 & $9 \cdot 5$ & $-0 \cdot 2$ & $8 \cdot 8$ & $0 \cdot 6$ & & $0 \cdot 7$ & $0 \cdot 5$ & $1 \cdot 4$ & $0 \cdot 9$ & $1 \cdot 4$ & $1 \cdot 0$ & \\
\hline Mean & $4 \cdot 2$ & $-0 \cdot 8$ & $7 \cdot 6$ & $-0 \cdot 1$ & $7 \cdot 5$ & $0 \cdot 1$ & $0 \cdot 25(0 \cdot 14)$ & $0 \cdot 8$ & $0 \cdot 1$ & $1 \cdot 2$ & $0 \cdot 6$ & $1 \cdot 3$ & $0 \cdot 6$ & $0 \cdot 10(0.06)$ \\
\hline \multicolumn{15}{|l|}{ Lettuce } \\
\hline 1-AW & $1 \cdot 5$ & $-0 \cdot 2$ & $1 \cdot 8$ & $0 \cdot 2$ & $1 \cdot 6$ & $0 \cdot 3$ & & $0 \cdot 5$ & $-0 \cdot 1$ & $0 \cdot 5$ & $-0 \cdot 1$ & $0 \cdot 5$ & $0 \cdot 2$ & \\
\hline $2-S S$ & $1 \cdot 2$ & $0 \cdot 2$ & $1 \cdot 6$ & $0 \cdot 4$ & 1.9 & $0 \cdot 1$ & & $0 \cdot 2$ & $0 \cdot 2$ & $0 \cdot 3$ & $0 \cdot 0$ & $0 \cdot 3$ & $0 \cdot 0$ & \\
\hline 3-AW & $1 \cdot 6$ & $-1 \cdot 0$ & $2 \cdot 9$ & $0 \cdot 1$ & $2 \cdot 6$ & $0 \cdot 5$ & & $0 \cdot 3$ & $0 \cdot 1$ & $0 \cdot 6$ & $-0 \cdot 2$ & $0 \cdot 6$ & $-0 \cdot 2$ & \\
\hline 4-SS & $1 \cdot 6$ & $-0 \cdot 8$ & $1 \cdot 8$ & $0 \cdot 0$ & $1 \cdot 8$ & $0 \cdot 1$ & & $0 \cdot 5$ & $0 \cdot 1$ & $0 \cdot 5$ & $-0 \cdot 2$ & $0 \cdot 4$ & $-0 \cdot 1$ & \\
\hline Mean & $1 \cdot 5$ & -0.5 & $2 \cdot 0$ & $0 \cdot 2$ & $2 \cdot 0$ & $0 \cdot 3$ & $0.09(0.04)$ & $0 \cdot 4$ & $0 \cdot 1$ & 0.5 & $-0 \cdot 1$ & 0.5 & $0 \cdot 0$ & $0.03(0.02)$ \\
\hline \multicolumn{15}{|l|}{ Fennel } \\
\hline 1-SS & $4 \cdot 9$ & $-1 \cdot 5$ & $4 \cdot 9$ & $0 \cdot 1$ & $4 \cdot 9$ & $0 \cdot 1$ & & $2 \cdot 6$ & $-0 \cdot 8$ & $2 \cdot 8$ & $-0 \cdot 2$ & $2 \cdot 9$ & $-0 \cdot 3$ & \\
\hline 2-AW & $3 \cdot 9$ & $-1 \cdot 0$ & $7 \cdot 5$ & $0 \cdot 1$ & $6 \cdot 8$ & 0.9 & & $1 \cdot 7$ & $-0 \cdot 2$ & $3 \cdot 8$ & $0 \cdot 2$ & $3 \cdot 2$ & $0 \cdot 8$ & \\
\hline $3-S S$ & $4 \cdot 9$ & $-0 \cdot 8$ & $6 \cdot 2$ & $1 \cdot 8$ & $6 \cdot 9$ & $1 \cdot 6$ & & $2 \cdot 9$ & -0.7 & $3 \cdot 8$ & $0 \cdot 3$ & $4 \cdot 1$ & $0 \cdot 4$ & \\
\hline 4-AW & $4 \cdot 8$ & $-3 \cdot 4$ & $4 \cdot 9$ & $0 \cdot 7$ & $5 \cdot 1$ & $0 \cdot 6$ & & $2 \cdot 3$ & $-1 \cdot 6$ & $2 \cdot 2$ & $0 \cdot 7$ & $2 \cdot 5$ & $0 \cdot 5$ & \\
\hline Mean & $4 \cdot 6$ & $-1 \cdot 7$ & $5 \cdot 9$ & $0 \cdot 7$ & $5 \cdot 9$ & $0 \cdot 8$ & $0 \cdot 43(0 \cdot 22)$ & $2 \cdot 4$ & $-0 \cdot 8$ & $3 \cdot 2$ & $0 \cdot 2$ & $3 \cdot 2$ & $0 \cdot 3$ & $0 \cdot 24(0 \cdot 12)$ \\
\hline \multicolumn{15}{|l|}{ Spinach } \\
\hline 1-SS & $1 \cdot 8$ & -0.5 & $2 \cdot 3$ & $1 \cdot 3$ & $2 \cdot 7$ & $0 \cdot 9$ & & $0 \cdot 6$ & $-0 \cdot 2$ & $0 \cdot 7$ & $0 \cdot 2$ & $0 \cdot 9$ & $-0 \cdot 1$ & \\
\hline 2-AW & $1 \cdot 1$ & -0.2 & $1 \cdot 6$ & $0 \cdot 4$ & $1 \cdot 6$ & $0 \cdot 4$ & & $0 \cdot 4$ & $-0 \cdot 1$ & $0 \cdot 5$ & $0 \cdot 0$ & $0 \cdot 5$ & $0 \cdot 0$ & \\
\hline $3-S S$ & $1 \cdot 8$ & $-1 \cdot 2$ & $1 \cdot 1$ & $1 \cdot 3$ & $1 \cdot 2$ & $1 \cdot 4$ & & $0 \cdot 5$ & $-0 \cdot 3$ & $0 \cdot 4$ & $0 \cdot 2$ & $0 \cdot 4$ & $0 \cdot 3$ & \\
\hline 4-AW & $1 \cdot 1$ & $0 \cdot 3$ & $1 \cdot 6$ & $0 \cdot 1$ & $1 \cdot 6$ & $0 \cdot 1$ & & $0 \cdot 2$ & $0 \cdot 2$ & $0 \cdot 4$ & $0 \cdot 0$ & $0 \cdot 3$ & $0 \cdot 0$ & \\
\hline Mean & $1 \cdot 5$ & -0.4 & $1 \cdot 6$ & $0 \cdot 8$ & $1 \cdot 8$ & $0 \cdot 7$ & $0 \cdot 19(0.09)$ & $0 \cdot 4$ & -0.1 & $0 \cdot 5$ & $0 \cdot 1$ & $0 \cdot 6$ & $0 \cdot 0$ & $0.08(0.04)$ \\
\hline
\end{tabular}

AW, autumn-winter; SS, spring-summer; S.E.D., standard error of difference among means for $\mathrm{N}$ treatment $\times$ rotation; in parenthesis, for $\mathrm{N}$ treatment. 
Table 5. Summary statistics of goodness-of-fit of EU-Rotate_N predictions for above-ground biomass, crop residues, biomass $\mathrm{N}$ concentration, $\mathrm{N}$ uptake by crops and soil mineral $\mathrm{N}$ (as $\mathrm{NO}_{3}-\mathrm{N}$ ) within the top $0.6 \mathrm{~m}$ soil for four biannual rotations of four vegetable crops at three $N$ input treatments in South Italy

\begin{tabular}{|c|c|c|c|c|c|}
\hline Variable and crop & ME (mod-obs) & PBIAS & MAE & Willmott's $d$ & $\mathrm{EF}$ \\
\hline \multicolumn{6}{|c|}{ Above-ground dry matter (t/ha) } \\
\hline Broccoli & $0 \cdot 31$ & $34 \cdot 7$ & $0 \cdot 32$ & 0.97 & $0 \cdot 87$ \\
\hline White cabbage & $-0 \cdot 28$ & $-11 \cdot 5$ & $0 \cdot 34$ & 0.99 & $0 \cdot 96$ \\
\hline Fennel & $0 \cdot 16$ & $8 \cdot 3$ & $0 \cdot 61$ & 0.96 & $0 \cdot 82$ \\
\hline Lettuce & -0.06 & $-8 \cdot 3$ & $0 \cdot 15$ & 0.97 & $0 \cdot 88$ \\
\hline Spinach & $0 \cdot 17$ & $21 \cdot 9$ & $0 \cdot 38$ & $0 \cdot 87$ & $0 \cdot 36$ \\
\hline \multicolumn{6}{|c|}{ Crop residues dry matter (t/ha) } \\
\hline Broccoli & $0 \cdot 49$ & $24 \cdot 6$ & $0 \cdot 49$ & $0 \cdot 77$ & $0 \cdot 22$ \\
\hline White cabbage & $0 \cdot 45$ & $41 \cdot 1$ & $0 \cdot 49$ & $0 \cdot 73$ & $-1 \cdot 39$ \\
\hline Fennel & -0.09 & $-2 \cdot 9$ & $0 \cdot 55$ & $0 \cdot 85$ & $0 \cdot 05$ \\
\hline Lettuce & $-0 \cdot 03$ & -8 & $0 \cdot 13$ & $0 \cdot 48$ & $-0 \cdot 6$ \\
\hline Spinach & $0 \cdot 01$ & $1 \cdot 6$ & $0 \cdot 14$ & $0 \cdot 75$ & $-0 \cdot 02$ \\
\hline \multicolumn{6}{|c|}{ Biomass $\mathrm{N}$ concentration $(\%)$} \\
\hline Broccoli & $0 \cdot 76$ & $19 \cdot 5$ & $0 \cdot 80$ & $0 \cdot 45$ & $-2 \cdot 23$ \\
\hline White cabbage & $0 \cdot 30$ & $9 \cdot 5$ & $0 \cdot 53$ & $0 \cdot 92$ & $0 \cdot 71$ \\
\hline Fennel & $0 \cdot 78$ & $25 \cdot 6$ & $0 \cdot 96$ & $0 \cdot 74$ & $-0 \cdot 30$ \\
\hline Lettuce & 0.65 & $19 \cdot 3$ & $1 \cdot 05$ & $0 \cdot 74$ & $-0 \cdot 27$ \\
\hline Spinach & $-0 \cdot 34$ & $-7 \cdot 3$ & $0 \cdot 66$ & $0 \cdot 59$ & $-0 \cdot 58$ \\
\hline \multicolumn{6}{|c|}{$\mathrm{N}$ uptake by crops (kg/ha) } \\
\hline Broccoli & $19 \cdot 63$ & 55 & $20 \cdot 18$ & $0 \cdot 93$ & $0 \cdot 72$ \\
\hline White cabbage & $0 \cdot 03$ & 0 & $16 \cdot 93$ & 0.97 & $0 \cdot 89$ \\
\hline Fennel & $18 \cdot 05$ & $32 \cdot 9$ & $24 \cdot 81$ & $0 \cdot 93$ & $0 \cdot 64$ \\
\hline Lettuce & $2 \cdot 41$ & $10 \cdot 6$ & $9 \cdot 35$ & 0.93 & 0.67 \\
\hline Spinach & $2 \cdot 34$ & $6 \cdot 6$ & $11 \cdot 76$ & $0 \cdot 92$ & $0 \cdot 71$ \\
\hline \multicolumn{6}{|c|}{ Soil mineral $\mathrm{N}$ content (kg/ha) } \\
\hline Broccoli & $-17 \cdot 8$ & $-14 \cdot 7$ & 34.93 & $0 \cdot 8$ & $0 \cdot 36$ \\
\hline White cabbage & $-80 \cdot 2$ & $-63 \cdot 2$ & $87 \cdot 86$ & $0 \cdot 45$ & $-0 \cdot 13$ \\
\hline Fennel & $-49 \cdot 6$ & $-44 \cdot 6$ & $53 \cdot 51$ & $0 \cdot 83$ & $0 \cdot 54$ \\
\hline Lettuce & $-76 \cdot 9$ & $-52 \cdot 3$ & $83 \cdot 24$ & $0 \cdot 64$ & $-0 \cdot 02$ \\
\hline Spinach & $-83 \cdot 5$ & $-62 \cdot 7$ & $88 \cdot 42$ & $0 \cdot 5$ & $-0 \cdot 38$ \\
\hline
\end{tabular}

negative to positive between $\mathrm{N} 0$ and $\mathrm{N} 1$, though mostly remaining within the confidence interval, and for the cabbage crops, where the tendency is similar, but residues for rotations 2 and 4 are over-predicted (Table 4 and Fig. 3). The ANOVA of prediction error, although confirming poor predictions for cabbage residues, shows a better agreement than the summary indices for spinach and lettuce, even if the coefficient of variation of residues for these crops were smaller (less tolerant of deviations) compared with those for broccoli and fennel, which score higher correlation indices.

\section{Crop $\mathrm{N}$ concentration}

Average $\mathrm{N}$ concentration in plants, on a dry weight basis, varied among crop species from $3 \%$ for fennel and cabbage, $3.4 \%$ for lettuce, $3.9 \%$ for broccoli and $4.7 \%$ for spinach and was slightly higher for springsummer crops $(3 \cdot 7 \%)$ compared with autumn-winter crops $(3 \cdot 5 \%)$, as shown in Table 6 . Positive $\mathrm{N}$ inputs generally increased $\mathrm{N}$ concentration, on average by between $9 \%$ for spinach and $32 \%$ for fennel, but with considerable variation among individual crops: the largest increase $(96 \%)$ was recorded for the autumnwinter crop of fennel in rotation 2 ; the lowest $(6 \%)$ for the spring-summer crop of spinach of rotation 3.

Summary statistics for crop $\mathrm{N}$ show a reasonably good fit of model predictions for white cabbage, with a moderate positive bias $(10 \%)$, over-prediction for broccoli, lettuce and fennel and under-prediction for spinach (Table 5). Cabbage $\mathrm{N}$ is over-predicted for the spring-summer crop in rotation 4 and under-predicted for the early stages of NO in rotation 1 (Fig. 4). 


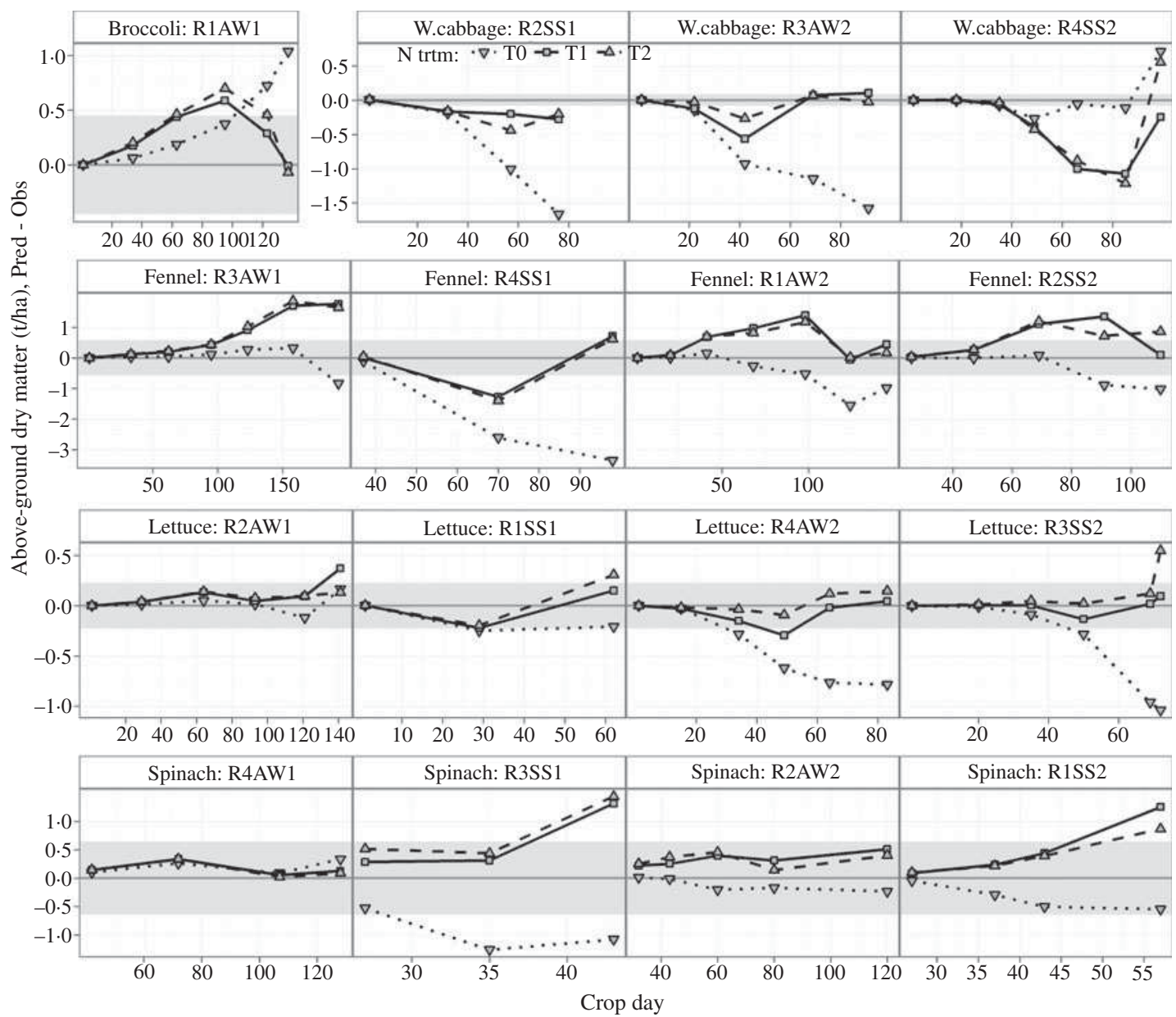

Fig. 2. EU-Rotate_N prediction error for above-ground dry matter biomass by crop stage, nitrogen treatments (N0, unfertilized control; N1, average recommended rate and N2, assumed average farmer's practice), rotations (R1 to R4) and seasons (AW, autumn-winter and SS, spring-summer). The confidence interval of the difference is shifted as a greycoloured band around zero.

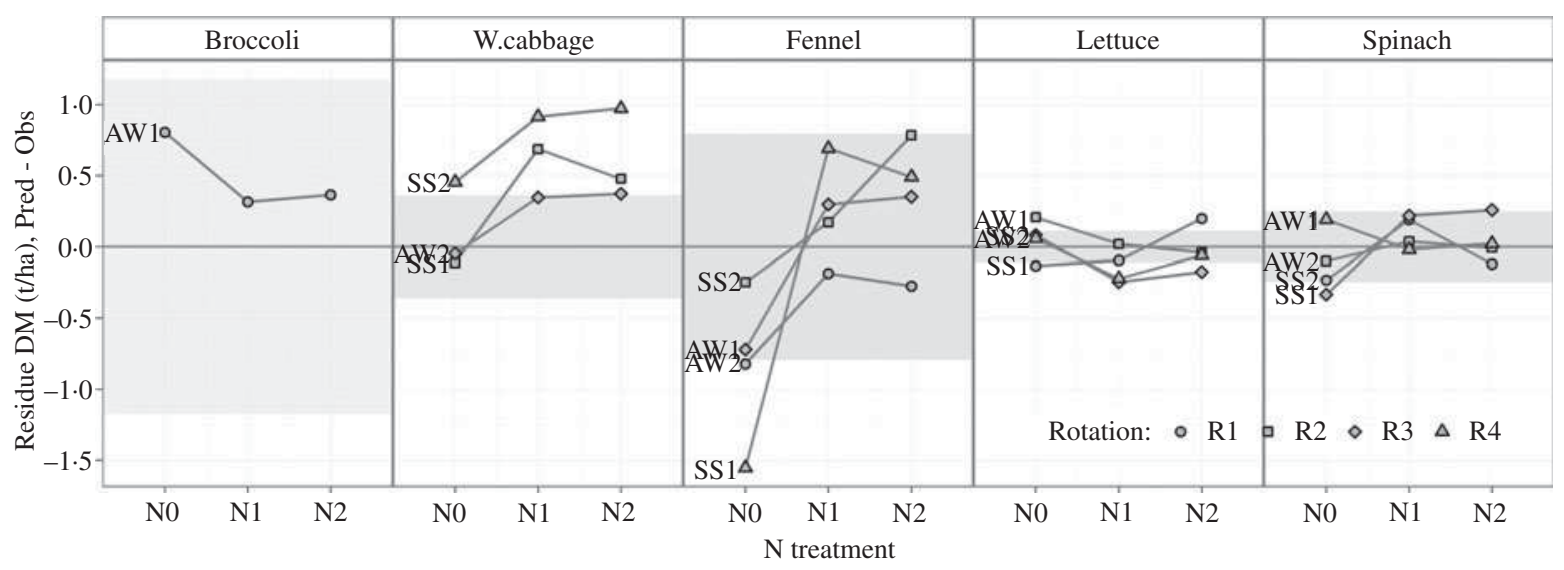

Fig. 3. EU-Rotate_N prediction error for dry matter of crop residues by nitrogen treatment ( $\mathrm{N}$, unfertilized control; $\mathrm{N} 1$, average recommended rate and N2, assumed average farmer's practice), rotations (R1 to R4) and seasons (AW, autumn-winter and SS, spring-summer). The confidence interval of the difference is shifted as a grey-coloured band around zero. 
Table 6. Means of observed $(O)$ and model-predicted minus observed $(P-O)$ values for $N$ concentration in above-ground biomass and crop $N$ uptake for five crops at three $N$ input treatments (NO, none; N1, recommended rate and N2, farmer's practice rate) in four rotations.

\begin{tabular}{|c|c|c|c|c|c|c|c|c|c|c|c|c|c|c|}
\hline \multirow{3}{*}{$\begin{array}{l}\text { Rotation, season } \\
\text { and crop }\end{array}$} & \multicolumn{7}{|c|}{ Biomass $\mathrm{N}$ concentration $(\%)$} & \multicolumn{7}{|c|}{ Crop N uptake (kg/ha) } \\
\hline & \multicolumn{2}{|c|}{ No } & \multicolumn{2}{|c|}{$\mathrm{N} 1$} & \multicolumn{2}{|c|}{ N2 } & \multirow[b]{2}{*}{ S.E.D. } & \multicolumn{2}{|c|}{ No } & \multicolumn{2}{|c|}{$\mathrm{N} 1$} & \multicolumn{2}{|c|}{ N2 } & \multirow{2}{*}{ S.E.D. } \\
\hline & $\mathrm{O}$ & $\mathrm{P}-\mathrm{O}$ & $\mathrm{O}$ & $\mathrm{P}-\mathrm{O}$ & $\mathrm{O}$ & $\mathrm{P}-\mathrm{O}$ & & $\mathrm{O}$ & $\mathrm{P}-\mathrm{O}$ & $\mathrm{O}$ & $\mathrm{P}-\mathrm{O}$ & $\mathrm{O}$ & $\mathrm{P}-\mathrm{O}$ & \\
\hline \multicolumn{15}{|l|}{ Broccoli } \\
\hline 1-AW & $3 \cdot 4$ & $1 \cdot 1$ & $4 \cdot 1$ & $0 \cdot 6$ & $4 \cdot 2$ & $0 \cdot 6$ & 0.06 & 43 & 72 & 150 & 3 & 160 & -3 & $12 \cdot 2$ \\
\hline \multicolumn{15}{|l|}{ White cabbage } \\
\hline 2-SS & $2 \cdot 4$ & $-0 \cdot 3$ & $3 \cdot 0$ & $0 \cdot 4$ & $3 \cdot 2$ & $0 \cdot 2$ & & 74 & -18 & 208 & 42 & 228 & 27 & \\
\hline 3-AW & $3 \cdot 5$ & $0 \cdot 0$ & $4 \cdot 0$ & $-0 \cdot 1$ & $4 \cdot 1$ & $-0 \cdot 1$ & & 131 & -45 & 164 & -8 & 171 & -10 & \\
\hline 4-SS & $2 \cdot 2$ & 0.7 & $2 \cdot 7$ & 0.9 & $2 \cdot 9$ & $0 \cdot 8$ & & 61 & 23 & 188 & 74 & 204 & 62 & \\
\hline Mean & $2 \cdot 7$ & $0 \cdot 2$ & $3 \cdot 2$ & $0 \cdot 4$ & $3 \cdot 4$ & $0 \cdot 3$ & $0.09(0.05)$ & 88 & -13 & 186 & 36 & 201 & 26 & $6 \cdot 7(3.9)$ \\
\hline \multicolumn{15}{|l|}{ Lettuce } \\
\hline 1-AW & $3 \cdot 3$ & -0.7 & $3 \cdot 5$ & $-0 \cdot 8$ & $3 \cdot 6$ & $-0 \cdot 8$ & & 50 & -17 & 71 & -24 & 66 & -19 & \\
\hline 2-SS & $3 \cdot 7$ & $1 \cdot 1$ & $4 \cdot 1$ & 0.9 & $4 \cdot 3$ & $0 \cdot 8$ & & 31 & 27 & 55 & 29 & 67 & 19 & \\
\hline 3-AW & $2 \cdot 5$ & $-0 \cdot 2$ & $3 \cdot 1$ & $1 \cdot 2$ & $3 \cdot 0$ & $1 \cdot 3$ & & 41 & -21 & 82 & 36 & 80 & 41 & \\
\hline 4-SS & $3 \cdot 0$ & $1 \cdot 0$ & $3 \cdot 2$ & $1 \cdot 1$ & $3 \cdot 3$ & $1 \cdot 1$ & & 45 & -8 & 55 & 25 & 57 & 25 & \\
\hline Mean & $3 \cdot 1$ & $0 \cdot 3$ & $3 \cdot 5$ & $0 \cdot 6$ & $3 \cdot 5$ & $0 \cdot 6$ & $0.08(0.04)$ & 42 & -5 & 66 & 17 & 68 & 16 & $4 \cdot 7(2 \cdot 4)$ \\
\hline \multicolumn{15}{|l|}{ Fennel } \\
\hline 1-SS & $3 \cdot 5$ & $0 \cdot 1$ & $3 \cdot 8$ & $0 \cdot 3$ & 3.9 & $0 \cdot 3$ & & 131 & -13 & 144 & 32 & 162 & 14 & \\
\hline 2-AW & $1 \cdot 5$ & $1 \cdot 4$ & $2 \cdot 7$ & $1 \cdot 2$ & $3 \cdot 0$ & $1 \cdot 0$ & & 41 & 18 & 160 & 59 & 165 & 67 & \\
\hline 3-SS & $2 \cdot 9$ & $0 \cdot 6$ & $3 \cdot 3$ & $1 \cdot 0$ & $3 \cdot 5$ & $1 \cdot 0$ & & 85 & 0 & 146 & 33 & 171 & 42 & \\
\hline 4-AW & $2 \cdot 3$ & 0.3 & $3 \cdot 0$ & $1 \cdot 1$ & $3 \cdot 1$ & $1 \cdot 0$ & & 84 & -46 & 128 & 62 & 144 & 47 & \\
\hline Mean & $2 \cdot 6$ & $0 \cdot 6$ & $3 \cdot 2$ & $0 \cdot 9$ & $3 \cdot 4$ & $0 \cdot 8$ & $0.06(0.03)$ & 85 & -10 & 145 & 46 & 160 & 43 & $10 \cdot 2(5 \cdot 1)$ \\
\hline \multicolumn{15}{|l|}{ Spinach } \\
\hline 1 -SS & $4 \cdot 4$ & -0.9 & 4.9 & -0.6 & $5 \cdot 0$ & -0.8 & & 52 & -15 & 92 & 13 & 112 & -7 & \\
\hline 2-AW & $4 \cdot 4$ & $0 \cdot 3$ & 4.9 & -0.5 & $4 \cdot 8$ & $-0 \cdot 4$ & & 36 & -8 & 67 & -3 & 71 & -6 & \\
\hline $3-S S$ & $4 \cdot 7$ & $-1 \cdot 0$ & $5 \cdot 1$ & $-1 \cdot 1$ & $5 \cdot 0$ & $-1 \cdot 1$ & & 108 & -26 & 74 & 6 & 67 & 23 & \\
\hline 4-AW & $4 \cdot 0$ & 0.7 & $4 \cdot 3$ & $0 \cdot 3$ & $4 \cdot 4$ & $0 \cdot 2$ & & 40 & 19 & 63 & 4 & 71 & -3 & \\
\hline Mean & $4 \cdot 4$ & $-0 \cdot 2$ & $4 \cdot 8$ & $-0 \cdot 5$ & $4 \cdot 8$ & -0.5 & $0.17(0.08)$ & 59 & -7 & 74 & 5 & 80 & 2 & $5 \cdot 6(2 \cdot 8)$ \\
\hline
\end{tabular}

AW, autumn-winter; SS, spring-summer; S.E.D., standard error of difference among means for $\mathrm{N}$ treatment $\times$ rotation; in parenthesis, for $\mathrm{N}$ treatment.

Predictions of fennel $\mathrm{N}$ are rather good for the autumnwinter crop in rotation 1, but biased upward in the other rotations, except for a good agreement in the final stage of the autumn-winter crop in rotation 3 and a downward bias for N0 in rotation 4. Predictions for lettuce $\mathrm{N}$ are mostly positively biased, except for early crop stages, the spring-summer crop of rotation 1 and the N0 treatment of rotation 3. Spinach N is predicted quite well for the autumn-winter crop of rotation 4 and not too badly for the corresponding crop of rotation 2, but under-predicted for spring-summer crops, in rotation 3 more than in rotation 1 .

\section{Crop $\mathrm{N}$ uptake}

Nitrogen uptake by crops was substantially higher for broccoli, cabbage and fennel than for spinach and lettuce. With no $\mathrm{N}$ input, average uptake by crop species varied from $42 \mathrm{~kg} / \mathrm{ha}$ for lettuce to $88 \mathrm{~kg} / \mathrm{ha}$ for cabbage (Table 6). Uptake was higher in springsummer compared with autumn-winter crops for lettuce, spinach and rotations 1 and 2 of cabbage, but lower for fennel. Except for the spring-summer crop of spinach in rotation 3, which did not succeed very well and showed decreasing $\mathrm{N}$ uptake with $\mathrm{N}$ fertilization, positive $\mathrm{N}$ input resulted in large increase in $\mathrm{N}$ uptake, ranging from $24 \%$ for the fennel crop in rotation 1 to $300 \%$ for the crop of the same species in rotation 2. The $\mathrm{N}$ input increase between $\mathrm{N} 1$ and $\mathrm{N} 2$ resulted in a moderate increase of $\mathrm{N}$ uptake for most crops, between 3 and $22 \%$.

Nitrogen uptake values were derived from aboveground dry matter and crop $\mathrm{N}$ concentration values and model predictions for this trait show an accuracy 


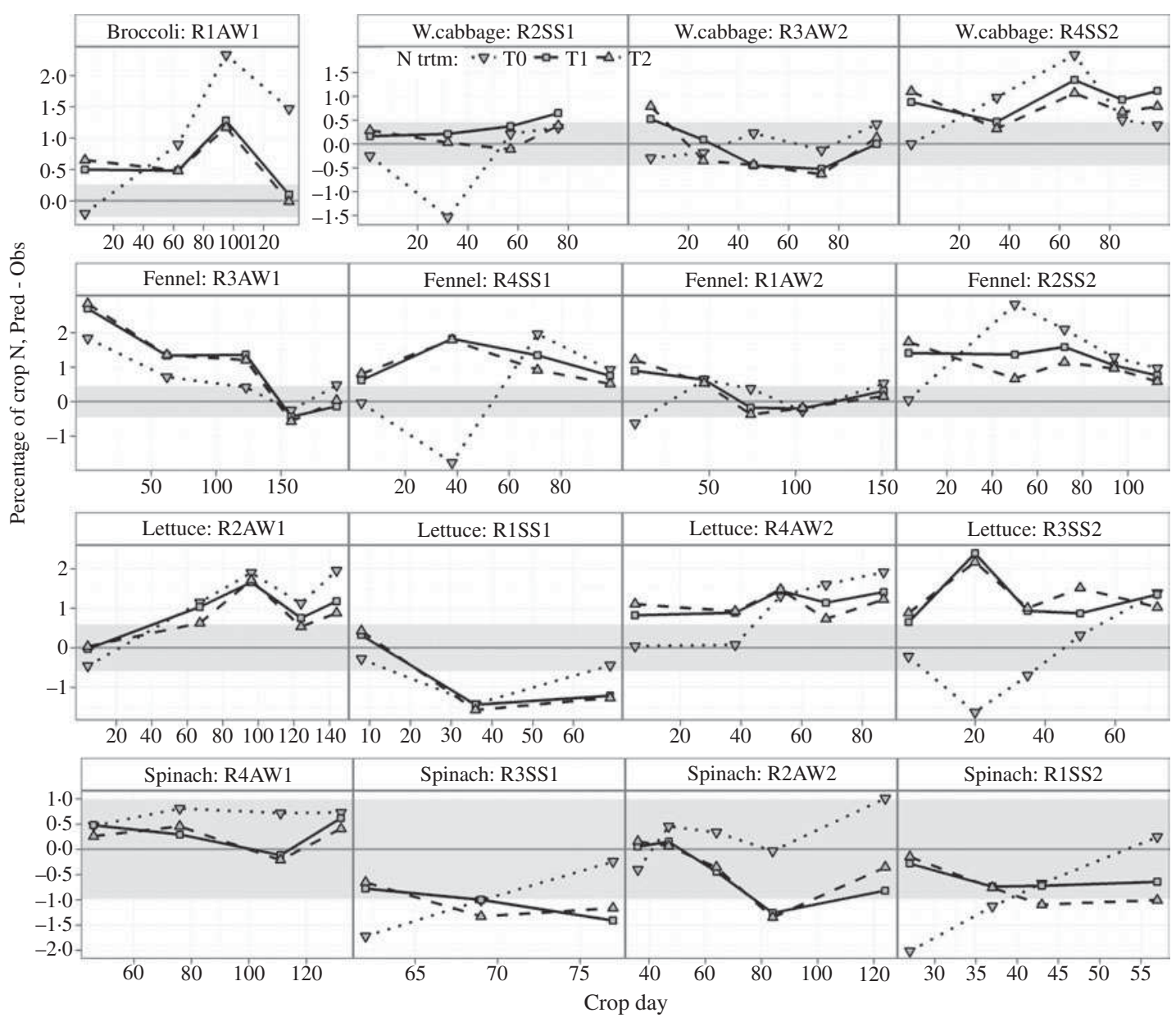

Fig. 4. EU-Rotate_ $N$ prediction error for biomass $N$ concentration by crop-stage, nitrogen treatment (N0, unfertilized control; N1, average recommended rate and N2, assumed average farmer's practice), rotations (R1 to R4) and seasons (AW, autumn-winter and SS, spring-summer). The confidence interval of the difference is shifted as a grey-coloured band around zero.

intermediate between those for the component traits, with good proportionality between predictions and observation ( $d$ in the range 0.92-0.97) and average efficiency of prediction (EF in the range $0 \cdot 64-0 \cdot 89$ ), but positive bias for broccoli, fennel, lettuce and spinach (Table 5). Overall, white cabbage shows the best summary statistics for this trait, followed by lettuce and spinach.

The error of prediction shows different trends in relation to crop stages among $\mathrm{N}$ input treatments and rotations, with a tendency to over-prediction for positive $\mathrm{N}$ fertilizer inputs in many crops (Fig. 5). Nitrogen uptake at the later stages of the springsummer crops of cabbage (rotations 2 and 4 ) is overpredicted, particularly for $\mathrm{N} 1$ and $\mathrm{N} 2$ treatments, while there is a tendency to under-predict for the same stages in the autumn-winter crop of rotation 3. Prediction of $\mathrm{N}$ uptake of broccoli is positively biased at an advanced stage for all $\mathrm{N}$ input treatments, but only for NO at the final stage. Fennel N uptake is predicted fairly well for the NO treatment but overpredicted for N1 and N2 in later crop stages in the first three rotations, while in the fourth for these treatments there is under-prediction at the advanced intermediate stage and over-prediction at the last, where the prediction for No is biased downward. For lettuce predictions are better in rotations 1 and 2, though not in the final crop stage; in rotation 1 the bias increases with crop stage and is negative for all $\mathrm{N}$ treatments; the same tendency is showed by the crop of rotation 4, but the bias is negative for N0 and positive for $\mathrm{N} 1$ and N2. Apart from the springsummer crop of rotation 3 , where $\mathrm{N}$ uptake of spinach is under-predicted for $\mathrm{N} 0$, there are few significant points of bad prediction for this trait in the other spinach crops. 


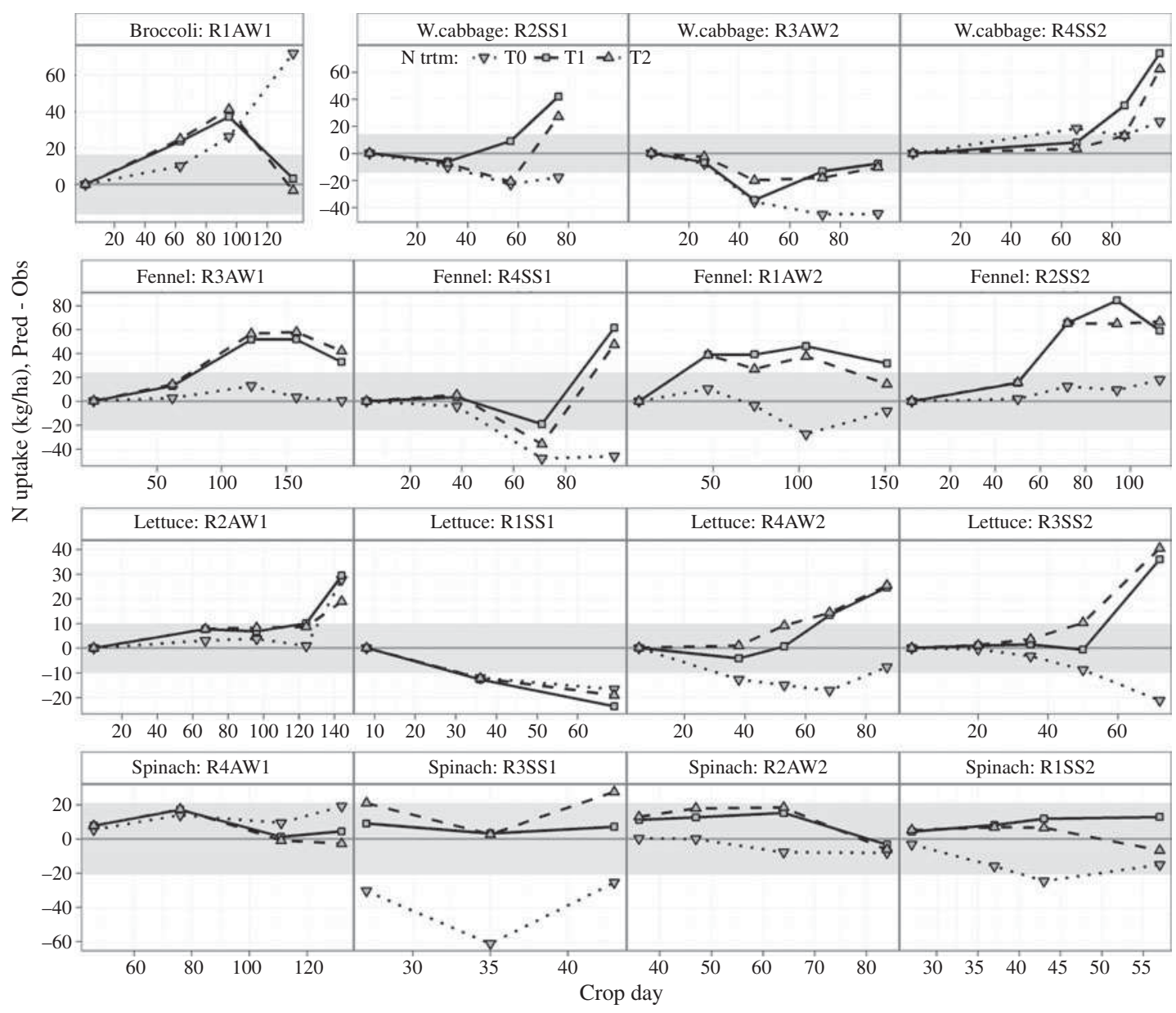

Fig. 5. EU-Rotate_N prediction error for crop $\mathrm{N}$ uptake by crop-stage, nitrogen treatment (N0, unfertilized control; N1, average recommended rate and N2, assumed average farmer's practice), rotations (R1 to R4) and seasons (AW, autumnwinter and SS, spring-summer). The confidence interval of the difference is shifted as a grey-coloured band around zero.

\section{Soil mineral $\mathrm{N}$}

Soil mineral $\mathrm{N}$ content in the $0-0.6 \mathrm{~m}$ layer, determined before planting and application of fertilizer and at harvest time, was obviously influenced by the $\mathrm{N}$ fertilizer inputs as the rotation progressed: relative to the level for N0, the available soil $\mathrm{N}$ at crop start increased on average by $32 \%$ with $\mathrm{N} 1$ and by $50 \%$ with $\mathrm{N} 2$, while the reduction on the pre-cropping level due to cultivation averaged 58, 30 and $23 \%$ for N0, N1 and N2, respectively (Table 7). High amounts of soil mineral $\mathrm{N}$ were available at the start of the autumnwinter crops of the third cycle: fennel in rotation 1, spinach in rotation 2, cabbage in rotation 3 and lettuce in rotation 4 , in proportion to the $\mathrm{N}$ input treatment. At harvest, however, the levels of soil $\mathrm{N}$ for these crops were not much different from those found in other cycles. For the spring-summer crops of lettuce in rotations 1 and 3 and of spinach in rotation 3 the end-crop level of soil $\mathrm{N}$ was considerably above the start level with the N1 and N2 input treatments. Such unbalances may have been due to enhanced mineralization.

Goodness-of-fit statistics show that the model underpredicted soil $\mathrm{N}$ for all crop species and particularly for spinach, cabbage and lettuce, but proportional agreement, as measured by Willmott's $d$ and EF, were not so bad for fennel and broccoli (Table 5). The ANOVA of prediction error shows that the inadequacies of predictions for cabbage and fennel were determined only by the very high soil $\mathrm{N}$ level at the start of these autumn-winter crops (rotations 3 and 1, respectively), the agreement for the other rotations being quite good (Fig. 6). Predictions for lettuce were affected by the same downward bias of high soil $\mathrm{N}$ levels at the start of rotation 4 , while it is the end-crop stage to be underpredicted for the spring-summer crop of rotation 3. The problem was similar for spinach in rotations 2 
Table 7. Means of observed $(O)$ and model-predicted minus observed $(P-O)$ for soil mineral $N$ content in the top $0.6 \mathrm{~m}$ by crops at the start and end of the cropping cycle for five crops at three $\mathrm{N}$ input treatments (NO, none; N1, recommended rate and N2, farmer's practice rate) in four rotations

\begin{tabular}{|c|c|c|c|c|c|c|c|c|c|c|c|c|c|}
\hline \multirow{3}{*}{$\begin{array}{l}\text { Rotation, season } \\
\text { and crop }\end{array}$} & \multicolumn{4}{|c|}{ No } & \multicolumn{4}{|c|}{ N1 } & \multicolumn{4}{|c|}{ N2 } & \multirow[b]{3}{*}{ S.E.D. } \\
\hline & \multicolumn{2}{|c|}{ Start } & \multicolumn{2}{|c|}{ End } & \multicolumn{2}{|c|}{ Start } & \multicolumn{2}{|c|}{ End } & \multicolumn{2}{|c|}{ Start } & \multicolumn{2}{|c|}{ End } & \\
\hline & $\mathrm{O}$ & $\mathrm{P}-\mathrm{O}$ & $\mathrm{O}$ & $\mathrm{P}-\mathrm{O}$ & $\mathrm{O}$ & $\mathrm{P}-\mathrm{O}$ & $\mathrm{O}$ & $\mathrm{P}-\mathrm{O}$ & $\mathrm{O}$ & $\mathrm{P}-\mathrm{O}$ & $\mathrm{O}$ & $\mathrm{P}-\mathrm{O}$ & \\
\hline \multicolumn{14}{|l|}{ Broccoli } \\
\hline 1-AW & 153 & -25 & 44 & -36 & 153 & -25 & 101 & -9 & 153 & -25 & 117 & 14 & $43 \cdot 5$ \\
\hline \multicolumn{14}{|l|}{ White cabbage } \\
\hline 2-SS & 46 & -27 & 29 & -20 & 56 & 2 & 50 & 3 & 74 & 0 & 93 & 21 & \\
\hline 3-AW & 225 & -189 & 47 & -38 & 489 & -426 & 130 & -60 & 545 & -456 & 208 & -106 & \\
\hline 4-SS & 42 & -30 & 56 & -47 & 44 & -30 & 55 & -34 & 42 & -26 & 54 & 20 & \\
\hline Mean & 104 & -82 & 44 & -35 & 196 & -152 & 78 & -30 & 220 & -161 & 118 & -21 & $18.9(10 \cdot 9)$ \\
\hline \multicolumn{14}{|l|}{ Lettuce } \\
\hline 1-AW & 44 & -36 & 94 & -59 & 101 & -10 & 277 & -74 & 117 & 13 & 399 & -139 & \\
\hline $2-S S$ & 122 & -30 & 46 & -33 & 122 & -30 & 56 & -5 & 122 & -30 & 74 & -6 & \\
\hline 3-AW & 49 & -46 & 56 & -24 & 57 & -55 & 271 & -213 & 65 & -62 & 356 & -264 & \\
\hline 4-SS & 190 & -169 & 58 & -40 & 280 & -217 & 97 & -38 & 348 & -232 & 126 & -49 & \\
\hline Mean & 101 & -70 & 63 & -39 & 140 & -78 & 175 & -82 & 163 & -78 & 239 & -114 & $41.9(20 \cdot 9)$ \\
\hline \multicolumn{14}{|l|}{ Fennel } \\
\hline 1-SS & 284 & -207 & 38 & -31 & 375 & -134 & 47 & -34 & 562 & -266 & 61 & -46 & \\
\hline 2-AW & 44 & -38 & 25 & -15 & 52 & -48 & 37 & -23 & 51 & -47 & 57 & -9 & \\
\hline $3-S S$ & 127 & 1 & 52 & -45 & 127 & 1 & 72 & -65 & 127 & 1 & 72 & -65 & \\
\hline 4-AW & 54 & -43 & 53 & -42 & 61 & 7 & 111 & -58 & 64 & 27 & 116 & -11 & \\
\hline Mean & 127 & -72 & 42 & -33 & 154 & -44 & 67 & -45 & 201 & -71 & 76 & -33 & $23 \cdot 5(11 \cdot 7)$ \\
\hline \multicolumn{14}{|l|}{ Spinach } \\
\hline 1-SS & 120 & -113 & 41 & -25 & 148 & -139 & 93 & -24 & 134 & -124 & 116 & -14 & \\
\hline 2-AW & 196 & -165 & 26 & -13 & 303 & -222 & 45 & -18 & 380 & -237 & 41 & -8 & \\
\hline $3-S S$ & 52 & -45 & 127 & -100 & 72 & -65 & 346 & -291 & 72 & -64 & 378 & -296 & \\
\hline 4-AW & 108 & -11 & 54 & -43 & 108 & -11 & 61 & 8 & 108 & -11 & 64 & 28 & \\
\hline Mean & 119 & -83 & 62 & -46 & 158 & -109 & 136 & -81 & 173 & -109 & 150 & -73 & $21 \cdot 3(10 \cdot 7)$ \\
\hline
\end{tabular}

AW, autumn-winter; SS, spring-summer; S.E.D., standard error of difference among means for $\mathrm{N}$ treatment $\times$ rotation; in parenthesis, for $\mathrm{N}$ treatment.

and 3, respectively; in addition, the start-crop levels were under-predicted also for the second springsummer crop in rotation 1 , while predictions were rather good for the first autumn-winter crop in rotation 4.

\section{DISCUSSION}

General model performance

The overall pattern of simulation results obtained using the EU-Rotate_N model under Mediterranean conditions are comparable to those achieved with other, well-established simulation models in international model comparisons (Kersebaum et al. 2007; Palosuo et al. 2011), in that crop variables were simulated with higher accuracy than the soil variables. Above-ground dry matter biomass predictions were almost unbiased and deviated little from the observed values, as did the simulations of crop residue biomass. Predictions of the $\mathrm{N}$ concentration in the above-ground biomass and, correspondingly, the total $\mathrm{N}$ uptake during the growth season were slightly over-predicted, for the latter to a greater extent at later crop stages of some crops. However, the model did reflect very well both the low initial $\mathrm{N}$ concentrations of the transplant, which were raised at low $\mathrm{N}$ supply for better root development in the juvenile phase, and the high $\mathrm{N}$ concentrations at later stages, which express luxury consumption of $\mathrm{N}$ above the critical concentration for the respective growth stage. Soil mineral $\mathrm{N}$ content was underpredicted substantially for six observations, otherwise it was modelled satisfactorily. Four of the observations occurred in late summer 2004, at the start of autumn 


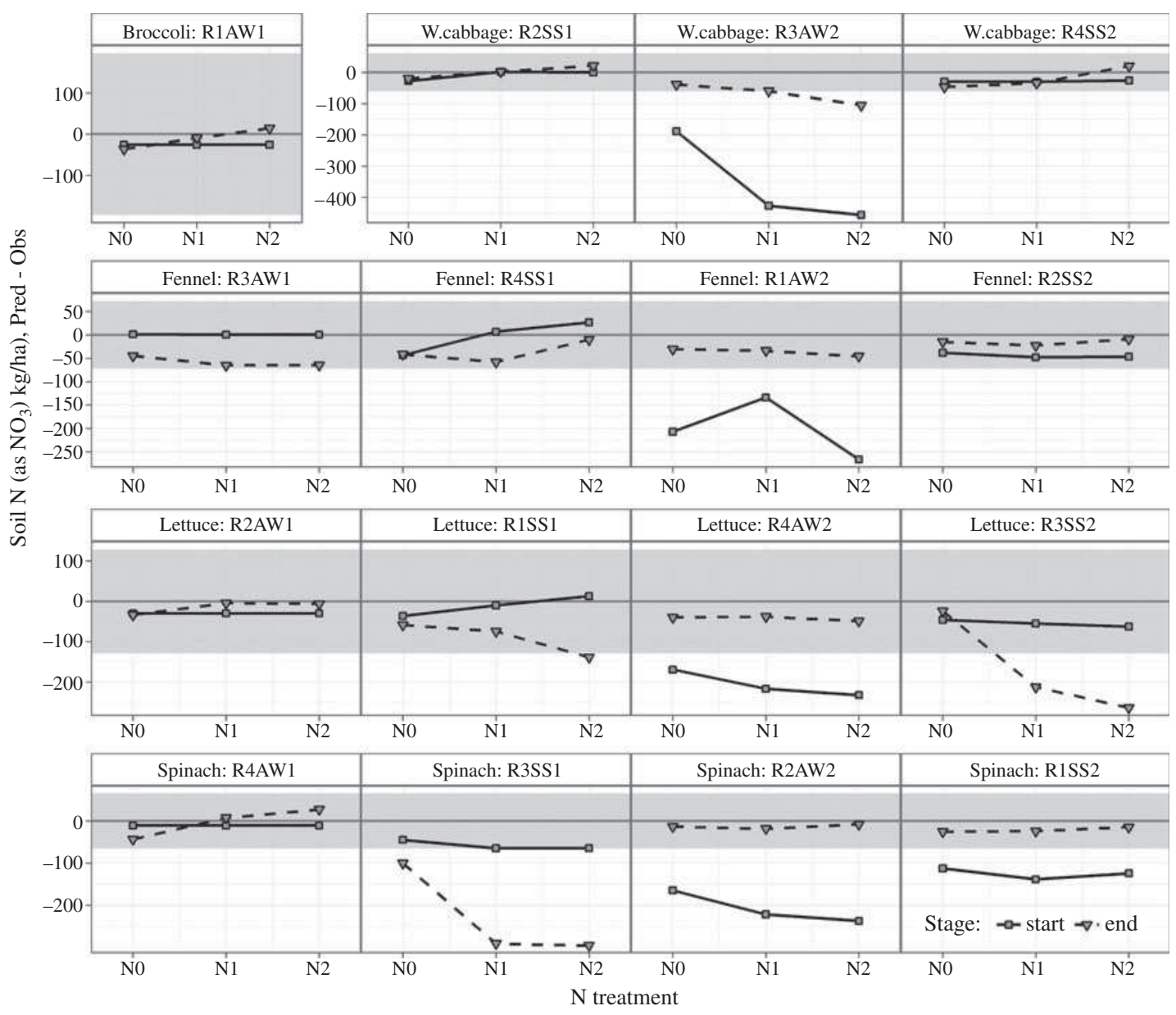

Fig. 6. EU-Rotate_N prediction error for $\mathrm{N}$ content (as $\mathrm{NO}_{3}-\mathrm{N}$ ) in the top $0 \cdot 6 \mathrm{~m}$ soil layer by crop-stage, nitrogen treatment (N0, unfertilized control; N1, average recommended rate and N2, assumed average farmer's practice), rotations (R1 to R4) and seasons (AW, autumn-winter and SS, spring-summer). The confidence interval of the difference is shifted as a greycoloured band around zero.

crops (fennel in the first rotation, spinach in the second, white cabbage in the third and lettuce in the fourth) and followed a warm and dry period of about 2 months, which may have considerably enhanced mineralization from organic $\mathrm{N}$ sources above the rate considered in the model for the reference climate (Fig. 1). Moreover, the short-lived spinach crops could have left unused soil $\mathrm{N}$, which contributed to the large amount measured at the start of the following crops.

The other two observations were the harvest of late spring crops (spinach in the first rotation and lettuce in the third). Both species prefer a colder environment and are less suitable for late spring, where the cropping cycle tend to be shortened; in addition, the weather at the end of these crop cycles was already favourable for high $\mathrm{N}$ mineralization rates; so it is possible that less nitrogen uptake and higher mineralization contributed to a build-up of excess soil mineral $\mathrm{N}$.
Taking account of this, the results obtained with EURotate_N are well in the range of those obtained with other simulation models for arable crops (Kersebaum et al. 2007), with the additional difficulty of being recalibrated neither for the simulated site nor for the simulated crops (Palosuo et al. 2011; Rötter et al. 2012). Furthermore, the results obtained under Mediterranean conditions were of a similar quality to those obtained under Central and Northern European conditions (Rahn et al. 2010).

Specific problems with the modelled system

The most obvious problem with the simulation of the Italian crop rotations was the fact that the model did not predict the high levels of soil mineral $\mathrm{N}$ for the six observations during the late summer of 2004 discussed above. The site history included vegetable crops with 
frequent catch crops of sunflower or broad beans for several years after conversion from a citrus orchard and this management could have contributed to the large amount of soil organic matter $(0 \cdot 035 \mathrm{~kg} / \mathrm{kg})$. The organic carbon content of the arable soil layer in the site area (Sele Plain) has been found to vary by soil district (24 districts) from 0.007 to $0.050 \mathrm{~kg} / \mathrm{kg}$, with an interquartile range of 0.009-0.016 and a median of $0.012 \mathrm{~kg} / \mathrm{kg}$ (observed in the region of Campania in 2002), so the experimental soil is unusually rich in organic carbon. However, the soil itself, which at the start of the experiment showed a $\mathrm{C}: \mathrm{N}$ ratio of 10 , cannot explain the high rates of $\mathrm{N}$ release observed, if common rate coefficients and temperature-moisture impact relations obtained from laboratory incubations are assumed (Sierra 1997; Crohn \& Valenzuela-Solano 2003). Nevertheless, increase of soil mineral $\mathrm{N}$ of more than $10 \mathrm{~g} \mathrm{~N} / \mathrm{m}^{2}$ within 3 months from late summer to early August 2004 were observed consistently in the control treatments and, correspondingly, increase of up to $30 \mathrm{~g} \mathrm{~N} / \mathrm{m}^{2}$ were observed in the respective fertilized treatments. The latter values cannot be explained either with the model or with current knowledge on organic matter decomposition. However, they are mainly responsible for the poor simulation result of this variable. Further work needs to be done to allow EU-Rotate_N to take account of these extreme conditions but in the meantime simulations can be adjusted by updating simulations with measured values where these errors are likely or the model can be pre-calibrated by adjusting the $\mathrm{N}$ turnover parameters.

In conclusion, the ability of the EU-Rotate_N model to simulate crops grown under Mediterranean conditions was broadly comparable with simulations obtained using Northern European data. In general, crop growth and $\mathrm{N}$ uptake patterns were well predicted; non-marketable yields less well. Soil $\mathrm{N}$ mineralization may not be well simulated in this particular instance, affecting the accuracy of prediction of soil mineral $\mathrm{N}$. However, soil mineral $\mathrm{N}$ values can be updated with measured values in the model on a seasonal basis to overcome this problem. Vegetable production systems, with their higher turnover of organic matter and higher use of fertilizer $\mathrm{N}$, pose considerable problems to crop modellers. In the light of not being calibrated prior to this exercise, the simulations results show the potential of the EU-Rotate_N model for use in vegetable rotations under warm and dry conditions of a Mediterranean climate.
The authors acknowledge funding from the EU Quality of Life Programme which supported the development of the EU-Rotate_N simulation model within the project QLK5-2002-01100 co-ordinated by C. Rahn at Warwick University. C. Nendel was additionally funded by ZALF budget funds.

\section{REFERENCES}

Agostini, F., Tel, F., Silgram, M., Farneselli, M., Benincasa, P. \& Aller, M.F. (2010). Decreasing nitrate leaching in vegetable crops with better $\mathrm{N}$ management. In Genetic Engineering, Biofertilisation, Soil Quality and Organic Farming (Ed. E. Lichtfouse), pp. 147-200. Sustainable Agriculture Reviews 4. Dordrecht, NL: Springer.

Allen, R. G., Pereira, L. S., Raes, D. \& Smith, M. (1998). Crop Evapotranspiration. Guidelines for Computing Crop Water Requirements. FAO Irrigation and Drainage Paper 56. Rome: FAO.

CAO, L. K., Chen, G. J. \& LU, Y. T. (2005). Nitrogen leaching in vegetable fields in the suburbs of Shanghai. Pedosphere 15, 641-645.

Cavero, J., Plant, R. E., Shennan, C., Friedman, D. B., Williams, J. R., KinIRY, J. R. \& Benson, V. W. (1999). Modeling nitrogen cycling in tomato-safflower and tomato-wheat rotations. Agricultural Systems 60, 123-135.

Crews, T. E. \& Peoples, M. B. (2005). Can the synchrony of nitrogen supply and crop demand be improved in legume and fertilizer-based agroecosystems? A review. Nutrient Cycling in Agroecosystems 72, 101-120.

Crohn, D. M. \& Valenzuela-Solano, C. (2003). Modeling temperature effects on decomposition. Journal of Environmental Engineering 129, 1149-1156.

DE PAZ, J.M. \& RAMOS, C. (2004). Simulation of nitrate leaching for different nitrogen fertilization rates in a region of Valencia (Spain) using a GIS-GLEAMS system. Agriculture Ecosystems and Environment 103, 59-73.

Dusenbury, M.P., Engel, R. E., Miller, P. R., Lemke, R. L. \& Wallander, R. (2008). Nitrous oxide emissions from a northern great plains soil as influenced by nitrogen management and cropping systems. Journal of Environmental Quality 37, 542-550.

Gallardo, M., Thompson, R. B., Lopez-Toral, J. R., Fernandez, M. D. \& Granados, R. (2006). Effect of applied $\mathrm{N}$ concentration in a fertigated vegetable crop on soil solution nitrate and nitrate leaching loss. In Acta Horticulturae (ISHS): Proceedings of the International Symposium towards Ecologically Sound Fertilisation Strategies for Field Vegetable Production 700, 221-224.

GreenwOOD, D.J. (2001). Modeling N-response of field vegetable crops grown under diverse conditions with N_ABLE: a review. Journal of Plant Nutrition 24, 17991815.

Greenwood, D.J., Rahn, C.R., Draycott, A., Vaidyanathan, L. V. \& Paterson, C. (1996). Modelling and measurement of the effects of fertilizer- $\mathrm{N}$ and crop residue incorporation on $\mathrm{N}$-dynamics in vegetable cropping. Soil Use and Management 12, 13-24. 
Guertal, E. A. (2009). Slow-release nitrogen fertilizers in vegetable production: a review. Horttechnology 19, 16-19.

Guo, R. Y., Nendel, C., Rahn, C. R., Jiang, C. G. \& Chen, Q. (2010). Tracking nitrogen losses in a greenhouse crop rotation experiment in North China using the EU-Rotate_N simulation model. Environmental Pollution 158, 22182229.

Halvorson, A. D., Bartolo, M. E., Reule, C. A. \& Berrada, A. (2008). Nitrogen effects on onion yield under drip and furrow irrigation. Agronomy Journal 100, 10621069.

Hansen, S., Jensen, H. E., Nielsen, N. E. \& Svendsen, H. (1991). Simulation of nitrogen dynamics and biomass production in winter-wheat using the Danish simulation-model DAISY. Fertilizer Research 27, 245-259.

JACKSON, L. E. (2000). Fates and losses of nitrogen from a nitrogen-15-labeled cover crop in an intensively managed vegetable system. Soil Science Society of America Journal 64, 1404-1412.

Jensen, L. S., Salo, T., Palmason, F., Breland, T. A., Henriksen, T. M., Stenberg, B., Pedersen, A., Lundström, C. \& ESALA, M. (2005). Influence of biochemical quality on C and $\mathrm{N}$ mineralisation from a broad variety of plant materials in soil. Plant and Soil 273, 307-326.

Kersebaum, K. C., Hecker, J.-M., Mirschel, W. \& Wegehenkel, M. (2007). Modelling water and nutrient dynamics in soil-crop systems: a comparison of simulation models applied on common data sets. In Modelling Water and Nutrient Dynamics in Soil-Crop Systems (Eds K.C. Kersebaum, J.-M. Hecker, W. Mirschel \& M. Wegehenkel), pp. 1-17. Dordrecht, NL: Springer.

Lafolie, F., Bruckler, L., de Cockborne, A. M. \& Laboucarie, C. (1997). Modeling the water transport and nitrogen dynamics in irrigated salad crops. Irrigation Science 17, 95-104.

Leenhardt, D., Lafolie, F., Bruckler, L. \& de Cockborne, A. M. (1998). Evaluating irrigation strategies for lettuce by simulation: 2. Nitrogen budget. European Journal of Agronomy 8, 267-282.

Lugato, E., Paustian, K. \& Giardini, L. (2007). Modelling soil organic carbon dynamics in two long-term experiments of north-eastern Italy. Agriculture Ecosystems and Environment 120, 423-432.

Mei, B. L., Zheng, X. H., Xie, B. H., Dong, H., Zhou, Z. X., Wang, R., Deng, J., Cul, F., Tong, H. \& Zhu, J. G. (2009). Nitric oxide emissions from conventional vegetable fields in southeastern China. Atmospheric Environment 43, 2762-2769.

Muhammetoglu, A. \& Yardimci, A. (2006). A fuzzy logic approach to assess groundwater pollution levels below agricultural fields. Environmental Monitoring and Assessment 118, 337-354.

Nash, J. E. \& Sutcliffe, J. V. (1970). River flow forecasting through conceptual models, Part I - A discussion of principles. Journal of Hydrology 10, 282-290.

NendeL, C. (2009). Evaluation of best management practices for $\mathrm{N}$ fertilisation in regional field vegetable production with a small-scale simulation model. European Journal of Agronomy 30, 110-118.
Nendel, C., Schmutz, U., Venezia, A., Piro, F. \& Rahn, C. R. (2009). Converting simulated total dry matter to fresh marketable yield for field vegetables at a range of nitrogen supply levels. Plant and Soil 325, 319-334.

Palosuo, T., Kersebaum, K. C., Angulo, C., Hlavinka, P., Moriondo, M., Olesen, J.E., Patil, R.H., Ruget, F., Rumbaur, C., Takáč, J., Trnka, M., Bındi, M., CaldaĞ, B., Ewert, F., Ferrise, R., Mirschel, W., Saylan, L., ŠıšKa, B. \& RÖTTER, R. (2011). Simulation of winter wheat yield and its variability in different climates of Europe. A comparison of eight crop growth models. European Journal of Agronomy 35, 103-114.

Pedersen, A., Zhang, K. F., Thorup-Kristensen, K. \& Jensen, L. S. (2010). Modelling diverse root density dynamics and deep nitrogen uptake - A simple approach. Plant and Soil 326, 493-510.

R Development Core Team (2011). R: A Language and Environment for Statistical Computing. Vienna, Austria: R Foundation for Statistical Computing.

RahN, C.R., ZanG, K. F., Lillywhite, R. D., Ramos, C., Doltra, J., de Paz, J.M., Riley, H., Fink, M., Nendel, C., Thorup-Kristensen, K., Pedersen, A., Piro, F., Venezia, A., Firth, C., Schmutz, U., Rayns, F. \& Strohmeyer, K. (2010). EU-Rotate_N - a European decision support system - to predict environmental and economic consequences of the management of nitrogen fertiliser in crop rotations. European Journal of Horticultural Science 75, 20-32.

Ramos, C., Agut, A. \& Lidon, A. L. (2002). Nitrate leaching in important crops of the Valencian Community region (Spain). Environmental Pollution 118, 215-223.

Rinaldi, M., Ventrella, D. \& Gagliano, C. (2007). Comparison of nitrogen and irrigation strategies in tomato using CROPGRO model. A case study from Southern Italy. Agricultural Water Management 87, 91-105.

Rötter, R.P., Palosuo, T., Kersebaum, K. C., Angulo, C., Bindi, M., Ewert, F., Ferrise, R., Hlavinka, P., Moriondo, M., Nendel, C., Olesen, J. E., Patil, R., Ruget, F., Takáč, J. \& TRNKA, M. (2012). Simulation of spring barley yield in different climatic zones of Northern and Central Europe - a comparison of nine crop models. Field Crops Research 133, 23-36.

Saxton, K. E., Rawls, W. J., Romberger, J. S. \& Papendick, R. I. (1986). Estimating generalized soil-water characteristics from texture. Soil Science Society of America Journal 50, 1031-1036.

Shaeffer, D. L. (1980). Model evaluation methodology applicable to environmental assessment models. Ecological Modelling 8, 275-295.

SierRA, J. (1997). Temperature and soil moisture dependence of $\mathrm{N}$ mineralization in intact soil cores. Soil Biology and Biochemistry 29, 1557-1563.

Stanski, H. R., Wilson, L. J. \& Burrows, W. R. (1989). Survey of Common Verification Measures in Meteorology. WMO World Weather Watch Technical Report 8, WMO/TD No. 358. Geneva, Switzerland: WMO.

Sutton, M. A., Oenema, O., Erisman, J.W., Leip, A., van GrinsVen, H. \& WinIWARTER, W. (2011). Too much of a good thing. Nature 472, 159-161.

WANG, Q. R., LI, Y. C. \& Klassen, W. (2007). Changes of soil microbial biomass carbon and nitrogen with cover crops 
and irrigation in a tomato field. Journal of Plant Nutrition 30, 623-639.

Westerveld, S. M., McKeown, A. W. \& McDonald, M. R. (2006). Seasonal nitrogen partitioning and nitrogen uptake of carrots as affected by nitrogen application in a mineral and an organic soil. Hortscience 41, 1332-1338.

Wiскнам, H. (2009). ggplot2: Elegant Graphics for Data Analysis. New York, USA: Springer.

Willmott, C. J. \& Wicks, D. E. (1980). An empirical method for the spatial interpolation of monthly precipitation within California. Physical Geography 1, 59-73.
Zambrano-Bigiarini, M. (2010). hydroGOF: Goodness-of-fit Functions for Comparison of Simulated and Observed Hydrological Time Series. R package, Version 0.2-1. Available from: http://www.rforge.net/hydroGOF/ (verified 23 July 2012).

Zotarelli, L., Dukes, M. D., Scholberg, J.M. S., MunozCARPenA, R. \& ICERMAN, J. (2009). Tomato nitrogen accumulation and fertilizer use efficiency on a sandy soil, as affected by nitrogen rate and irrigation scheduling. Agricultural Water Management 96, 12471258. 